$11-2006$

\title{
Ozone Variability in the Midlatitude Upper Troposphere and Lower Stratosphere Diagnosed from a Monthly SAGE II Climatology Relative to the Tropopause
}

\author{
Pi-Huan Wang \\ Derek M. Cunnold \\ Charles R. Trepte \\ Hsiang J. Wang \\ Ping Jing \\ Loyola University Chicago, pjing@luc.edu
}

Follow this and additional works at: https://ecommons.luc.edu/ies_facpubs

Part of the Environmental Studies Commons

\section{Recommended Citation \\ Wang, P.-H., D. M. Cunnold, C. R. Trepte, H. J. Wang, P. Jing, J. Fishman, V. G. Brackett, J. M. Zawodney, andG. E. Bodeker (2006), Ozone variability in the midlatitude upper troposphere and lower stratosphere diagnosed from a monthlySAGE II climatology relative to the tropopause, J. Geophys. Res., 111, D21304, doi:10.1029/2005JD006108.}

This Article is brought to you for free and open access by the Faculty Publications and Other Works by Department at Loyola eCommons. It has been accepted for inclusion in School of Environmental Sustainability: Faculty Publications and Other Works by an authorized administrator of Loyola eCommons. For more information, please contactecommons@luc.edu.

\section{(c) (i) $\Theta$}

This work is licensed under a Creative Commons Attribution-Noncommercial-No Derivative Works 3.0 License. (c) The American Geophysical Union, 2006. 


\title{
Ozone variability in the midlatitude upper troposphere and lower stratosphere diagnosed from a monthly SAGE II climatology relative to the tropopause
}

\author{
Pi-Huan Wang, ${ }^{1}$ Derek M. Cunnold ${ }^{2}$ Charles R. Trepte, ${ }^{3}$ Hsiang J. Wang, ${ }^{2}$ Ping Jing, ${ }^{2}$ \\ Jack Fishman, ${ }^{3}$ Vince G. Brackett, ${ }^{4}$ Joseph M. Zawodney, ${ }^{3}$ and Greg E. Bodeker ${ }^{5}$ \\ Received 25 April 2005; revised 26 May 2006; accepted 30 May 2006; published 11 November 2006.
}

[1] A midlatitude $\left(25^{\circ}-65^{\circ}\right)$ monthly zonal median ozone climatology in the upper troposphere and lower stratosphere (UTLS), from 8 to $20 \mathrm{~km}$ with a $0.5-\mathrm{km}$ vertical resolution and a $5^{\circ}$ latitudinal resolution, is developed on the basis of version 6.2 (V6.2) ozone profile retrievals from the Stratospheric Aerosol and Gas Experiment (SAGE) II measurements from October 1984 to August 2005. To avoid mixing of the tropospheric ozone data with stratospheric values, the thermal tropopause height is used as a base altitude for developing the climatology (the monthly mean tropopause height has been added back to the climatological profile). This feature of the developed ozone climatology, together with the near global SAGE II data coverage, complements the existing ozone climatologies in the midlatitude UTLS. In addition to using this climatology to describe hemispheric differences in the UTLS ozone (the primary purpose of this paper), the database can also be used to initialize atmospheric chemistry-transport models or for satellite data retrieval. The specific new findings include (1) the differences in the vertical structure of monthly ozone evolution across the tropopause between the $\mathrm{NH}$ and the $\mathrm{SH},(2)$ all year bimodal probability distribution functions (PDFs) of the tropopause ozone, and (3) the annual cycle of the tropopause ozone PDF with increasing (decreasing) presence of ozone-rich air leading to tropopause ozone enhancements (reductions) during spring and early summer (fall and winter). The derived climatology is shown to be consistent with the ozonesonde climatologies of Logan $(1985,1999$ a) in many respects, including ozone seasonal cycle at the tropopause and in the UT, the broad summer ozone maximum in the northern UT, and non-Gaussian ozone PDFs at the tropopause. This consistency strengthens the confidence in SAGE II satellite ozone remote sensing in the UTLS. The derived SAGE II midlatitude ozone climatology is compared to ozonesonde measurements at Hohenpeissenberg $\left(47.4^{\circ} \mathrm{N}, 11^{\circ} \mathrm{E}\right)$, Germany, and Lauder $\left(45^{\circ} \mathrm{S}\right.$, $\left.169.7^{\circ} \mathrm{E}\right)$, New Zealand. The monthly ozone climatology data are provided as auxiliary material to this report.

Citation: Wang, P.-H., D. M. Cunnold, C. R. Trepte, H. J. Wang, P. Jing, J. Fishman, V. G. Brackett, J. M. Zawodney, and G. E. Bodeker (2006), Ozone variability in the midlatitude upper troposphere and lower stratosphere diagnosed from a monthly SAGE II climatology relative to the tropopause, J. Geophys. Res., 111, D21304, doi:10.1029/2005JD006108.

\section{Introduction}

[2] The ozone properties in the upper troposphere and lower stratosphere (UTLS) are important to the understand-

\footnotetext{
${ }^{1}$ Science and Technology Corporation, Hampton, Virginia, USA.

${ }^{2}$ School of Earth and Atmospheric Sciences, Georgia Institute of Technology, Atlanta, Georgia, USA.

${ }^{3}$ Science Directorate, NASA Langley Research Center, Hampton, Virginia, USA.

${ }^{4}$ Science Applications International Corp., Hampton, Virginia, USA.

${ }^{5}$ National Institute of Water and Atmospheric Research, Lauder, Central Otago, New Zealand.
}

Copyright 2006 by the American Geophysical Union. 0148-0227/06/2005JD006108 ing of the global chemistry and climate interaction [World Meteorological Organization (WMO), 1998; Intergovernmental Panel on Climate Change, 2001; Integrated Global Observing Strategy (IGOS), 2004]. For this reason, the ozone behavior as well as the chemical and transport processes that affect the ozone distribution in the UTLS have been the subject of extensive investigations [e.g., Holton et al., 1995; Logan, 1999a, 1999b; Seo and Bowman, 2002; Stohl et al., 2003a; Schoeberl, 2004; Jing et al., 2004, 2005]. Significant advancement of information on the ozone behavior in the UTLS has been made in recent years [e.g., Logan, 1999a, 1999b]. It is understood that the troposphere is not just a simple sink for stratospheric ozone. 
It has its own complex biogenic and anthropogenic ozone sources [e.g., Lelieveld and Dentener, 2000]. Thus, to characterize the ozone behavior in the UTLS is still a great challenge [e.g., IGOS, 2004].

[3] Previously, we have employed an earlier version of the ozone data between 1985 and 1991 derived from the Stratospheric Aerosol and Gas Experiment (SAGE) II to study the ozone properties in the middleworld on a seasonal basis [Wang et al., 1998a]. The SAGE II ozone seasonal variations in the middleworld were shown to be consistent with the conceptual role of eddy quasi-adiabatic transport [e.g., Holton et al., 1995], and the model-calculated annual cycle of the diabatic circulation [e.g., Rosenlof, 1995]. Recently, SAGE II northern midlatitude ozone data have been used to study the isentropic ozone stratospheretroposphere exchange (STE) by Jing et al. [2004]. Their results indicate that isentropic ozone STE is associated with wavebreaking and occurs preferentially over the eastern Atlantic Ocean and northern Africa in winter and over the Atlantic and Pacific Oceans in summer, consistent with the findings of Postel and Hitchman [1999].

[4] A number of extensive ozone climatologies are currently available [Fortuin and Kelder, 1998; Logan, 1999a, 1999b; Logan and McPeters, 1999]. Some existing climatologies were developed on the basis of ozonesonde data alone [e.g.,Logan, 1999a, 1999b], and others used a combination of ozonesonde and satellite data sets [e.g., Fortuin and Kelder, 1998; Logan and McPeters, 1999]. It is our primary objective to develop a monthly midlatitude ozone climatology to improve current understanding of ozone behavior in the UTLS by using the entire retrieval of version 6.2 (v6.2) SAGE II data (October 1984 to August 2005). Certainly, each type of data has its advantages. The main advantage of SAGE is its spatial coverage, especially beyond northern midlatitudes and in the SH. In addition, SAGE II is a very stable self-calibrated satellite instrument [McCormick, 1987]. Its long-term high quality near global ozone data since October 1984 have been used extensively in the international ozone trend assessment [e.g., $W M O$, 1998, 2003], and in ozone climatology development [e.g., Logan and McPeters, 1999].

[5] Using ozonesonde data from 14 ground stations, Wang et al. [2002] have examined the quality of the SAGE II ozone (v6.1) data in detail. The SAGE II data between 1985 and 2000 are shown to agree with the ozonesonde data to within $10 \%$ down to the tropopause. In the region between $8 \mathrm{~km}$ altitude and $2 \mathrm{~km}$ below the tropopause, the SAGE II retrieval systematically underestimates the ozone concentration. They further pointed out that the version v6.1 retrieval features improvement from the previous version in many areas, including better treatment of the wavelength dependence of the atmospheric refraction, the oblateness of the Earth, and the solar edge crossing time determination when the Sun is obscured by clouds or the Earth's surface. In addition, a finer tangent altitude bin of $0.5 \mathrm{~km}$ is used for v6.1 data retrieval [Wang et al., 2002].

[6] The recently released version 6.2 (v6.2) SAGE II data set is primarily focused on improving the water vapor retrieval and the correction of an altitude registration problem stemming from faulty spacecraft ephemeris data [Iyer et al., 2003]. The altitude registration correction affects SAGE II data products in late 2000 and beyond. As indicated by
Logan [1999a], a vertical resolution of about $1 \mathrm{~km}$ is required in chemical models to resolve the annual cycle phase changes and the steep gradients of ozone concentration across the tropopause. The solar occultation technique is the only method that has a chance of achieving such a requirement in satellite ozone remote sensing. With the entire v6.2 SAGE II data from October 1984 to August 2005 , it is possible to carry out an even more detailed analysis on the behavior of ozone and STE in the midlatitude UTLS than in earlier studies.

[7] The objectives of the present study are to (1) develop a monthly ozone climatology in the midlatitude UTLS that can be used to initialize global atmospheric chemistrytransport models and satellite data retrievals, (2) extend our previous ozone analysis by examining the ozone properties in the UTLS on a monthly basis, (3) investigate the relationship between the tropopause height and tropopause ozone at midlatitudes, (4) explore the timing of the presence of ozone-rich and ozone-poor air at the midlatitude tropopause and relate this to STE processes by analyzing the monthly evolution of ozone probability distribution functions (PDFs), (5) compare features of the midlatitude SAGE II ozone climatology with observations from ozonesondes, and (6) examine the difference in ozone behavior between the Northern Hemisphere $(\mathrm{NH})$ and the Southern Hemisphere (SH). Following the idea of Logan [1999a], the tropopause height is used as a base altitude for the climatology. The associated meteorological information of monthly mean air density, temperature, and pressure are also included in the climatology. The pressure-height information facilitates the conversion of profiles of the derived ozone climatology to profiles at standard pressure levels. In the following presentation, we discuss the relevant aspects of data used in this study and the method of analysis in section 2 . The derived monthly ozone climatology is described in section 3 with highlights on some specific features, including monthly tropopause ozone evolution and its implications of the STE, as well as hemispheric difference in ozone properties. The summary, discussions, and conclusions are presented in section 4.

\section{Data and Analysis}

[8] The data employed for the present study include the latest SAGE II ozone retrieval (v6.2) and ozonesonde measurements obtained at Hohenpeissenberg $\left(47.4^{\circ} \mathrm{N}\right.$, $\left.11^{\circ} \mathrm{E}\right)$, Germany $(1985-2005)$, and Lauder $\left(45^{\circ} \mathrm{S}\right.$, $\left.169.7^{\circ} \mathrm{E}\right)$, New Zealand (1986-2005). The main reason for incorporating ozone data from these two ozonesonde stations into the present study is that they have a sufficient and outstanding long-term ozone data record comparable to that from the SAGE II multiyear observations. They provide an excellent opportunity to evaluate the properties of the SAGE II ozone data product in terms of both ozone profile measurements and ozone climatological characteristics in the midlatitude UTLS. It should be noted that the SAGE II instrument makes up to 15 sunrise and 15 sunset occultation measurements each day. The consecutive measurements are separated by $24.5^{\circ}$ in longitude and slightly in latitude, and the latitudinal shift is larger at the equator than at midlatitudes. It takes about a month to complete near global coverage [McCormick, 1987; Chu et al., 1989]. SAGE II 
multiyear observations, which have less frequent cloud obscuration in the extratropics than in the tropics [Wang et al., 1996], are particularly suitable for studying the ozone behavior in the midlatitude UTLS on a monthly basis. Also included in the present study is the associated meteorological information, including thermal tropopause height, provided to the SAGE II data processing team by the National Centers for Environmental Prediction (NCEP) [e.g., Chu et al., 1989].

[9] To compare the SAGE II ozone profiles with ozonesonde data, only SAGE II and ozonesonde measurement pairs obtained on the same day, within $1000 \mathrm{~km}$ in longitude, and within $5^{\circ}$ of latitude are employed. Wang et al. [2002] have recommended removal of SAGE II ozone measurements with an error estimate of $300 \%$ or greater for comparison with ozonesonde observations. Generally, the SAGE II ozone data with large uncertainties are associated with measurements having very low ozone concentration, i.e., at low altitudes [Wang et al., 2002]. Our investigation indicates that the magnitude of the estimated uncertainty is correlated with the degree of the low bias of the SAGE II tropospheric data with respect to ozonesonde measurements. For this reason, only data with uncertainty up to $200 \%$ are employed in the present ozone climatology investigation. Figure 1 provides the statistics of the SAGE II ozone uncertainty estimate at the northern midlatitudes. Generally speaking, the percentage of uncertainty estimate increases as the altitude decreases.

[10] Since high aerosol loading affects the SAGE II ozone retrieval [Cunnold et al., 1996], the SAGE II ozone data collected during the unusually high aerosol loading period between June 1991 and November 1993 from the Mt. Pinatubo $\left(15.1^{\circ} \mathrm{N}, 120.4^{\circ} \mathrm{E}\right)$ volcanic eruption are excluded from the present study. In addition, ozone measurements in the presence of clouds along the SAGE II instrument viewing path as detected by using the two-wavelength method of Kent et al. [1993] are also rejected from the present investigation.

[11] To develop the monthly ozone climatology, the SAGE II v6.2 ozone data are binned into $5^{\circ}$ latitude bins between $22.5^{\circ}$ and $67.5^{\circ}$ in both hemispheres. As will be shown, the relatively large number of midlatitude profile measurements from the entire SAGE II observations (1984-2005) facilitate the development of the monthly ozone climatology in the midlatitude UTLS and exploration of the differences between ozone properties in the two hemispheres with unprecedented detail. As indicated in the Introduction, one of the objectives of the present study concerns the cross tropopause transport. To achieve this objective, the SAGE II ozone profile measurements are systematically combined by using the thermal tropopause as the base altitude for the climatology. This treatment of ozone data is important for understanding the ozone properties around the tropopause. It avoids mixing of tropospheric ozone and stratospheric values, which would inevitably happen if the data at the same altitude were grouped together. A recent study of Logan [1999a] favors the use of the thermal tropopause to provide a separation of the tropospheric and stratospheric ozone values. As she noted, the tropopause ozone values vary from tens of parts per billion ( $\mathrm{ppb}$ ) to a few values over $300 \mathrm{ppb}$, revealing that the thermal tropopause represents a transition between
SAGE II $0_{3}$ Uncertainty Estimate Statistics (1984-2005)

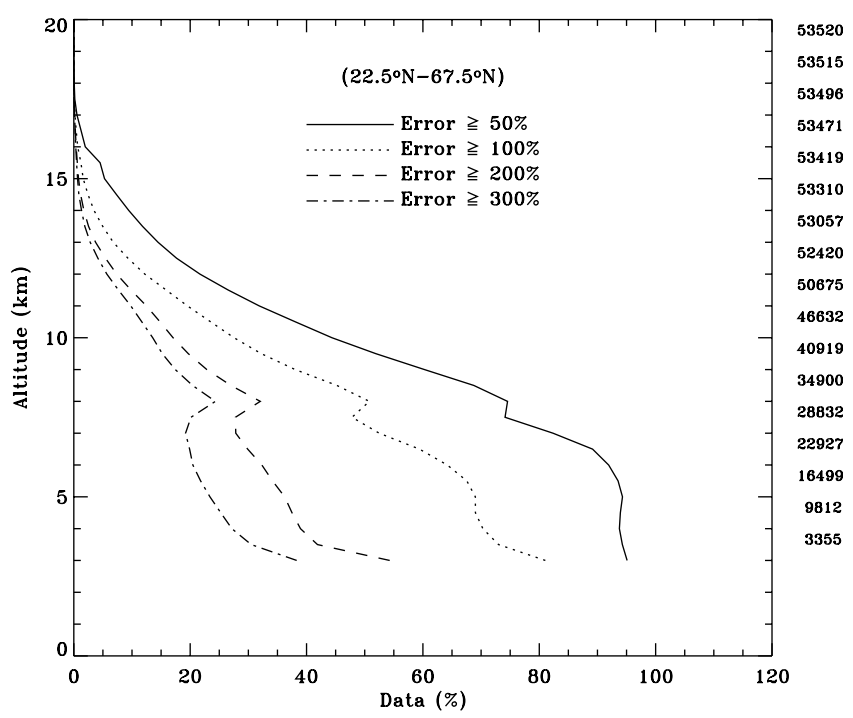

Figure 1. SAGE II ozone uncertainty estimate statistics $(1984-2005)$ at $22.5^{\circ} \mathrm{N}-67.5^{\circ} \mathrm{N}$. The numbers on the right indicate the corresponding sample size of SAGE II in the northern midlatitudes.

ozone concentrations typically associated with the troposphere (less than $\sim 120 \mathrm{ppb}$ ) and those found in the lower stratosphere greater than $\sim 300 \mathrm{ppb}$ [Logan, 1999a]. It is noted that a detailed study of ozone properties relative to the tropopause is also included in the ozonesonde climatology of Logan [1999a] (the data with respect to the tropopause along with the ozonesonde climatology are available at ftp:// ftp.as.harvard.edu/pub/sonde/tropp).

[12] Three steps are involved in the data processing. First, a new reference vertical coordinate system is formulated by using the NCEP thermal tropopause as the first vertical level, i.e., the new origin, and employing the same vertical resolution $(0.5 \mathrm{~km})$ as the SAGE II data. Each ozone profile from the original SAGE II geometric coordinate system is then interpolated to this new vertical coordinate system and is combined with other converted ozone profiles to provide monthly median profiles related to the tropopause. Finally, the derived monthly median ozone profile is converted back to the SAGE II original vertical coordinate system (relative to the surface) by adding the monthly mean tropopause height to the new vertical coordinate system, which uses the tropopause as the first level. The definition of the tropopause height in the NCEP data set follows the standard thermal tropopause definition, i.e., the altitude above which a temperature lapse rate of $2{ }^{\circ} \mathrm{C} / \mathrm{km}$ is maintained for at least $2 \mathrm{~km}$ and which is above the $500 \mathrm{hPa}$ level [WMO, 1957; Bethan et al., 1996; Randel et al., 2000]. The same data grouping approach is applied to ozonesonde data. The ozonesonde tropopause follows the same definition as in the NCEP data set. The uncertainty in tropopause height is difficult to estimate. Randel et al. [2000] showed that the NCEP tropopause is too high in pressure by $\sim 2-6 \mathrm{hPa}$ with respect to radiosondes in the tropics and that the bias is approximately constant in time (1957-1997). Bethan et al. [1996] showed that, over Europe, the majority of tempera- 
ture profiles from radiosondes reveal a well defined tropopause with a height difference of less than $0.5 \mathrm{~km}$ between the thermal tropopause and an upper tropospheric lapse rate of $5 \mathrm{~K} / \mathrm{km}$. This height difference is referred to as the sharpness of the thermal tropopause by Bethan et al. [1996], and is regarded as a gross measure of the tropopause uncertainty. In the presentation below we will simply refer to the tropopause as the thermal tropopause.

[13] As will be shown below, the ozone data around the tropopause reveal a PDF whose shape is notably different from Gaussian [e.g., Logan, 1999a; Rood et al., 2000; Wang et al., 2002]. For this reason, the present study uses the median instead of the mean in the ozone climatology. The range of the associated 16th and 84th percentiles, which correspond to the range of two standard deviations for a normal distribution, is used to represent the data spread, i.e., variability, of the derived median.

\section{Results}

\subsection{Data Pair Comparison}

[14] The results of the data pair comparison between SAGE II and ozonesondes at Hohenpeissenberg are presented in Figure 2. Monthly pair differences are within $20 \%$ at the tropopause plus $1 \mathrm{~km}$, and the differences are smaller at higher altitudes. Below the tropopause, the differences increase as the altitude decreases, and the SAGE II ozone is systematically biased low with the monthly pair difference greater than $50 \%$ at $6 \mathrm{~km}$. The small SAGE II sample size at low altitudes resulting from opaque cloud presence may contribute to the poor agreement below $10 \mathrm{~km}$. Both the SAGE II and the ozonesonde measurements reveal quite similar seasonal characteristics in the ozone vertical distribution. Note the appearance of the S-shape of the median ozone profile just above the tropopause in May in both SAGE II and ozonesondes (Figure 2), which is notably different from the median ozone distribution in December. To examine the S-shape ozone profile development more closely, the SAGE II monthly median ozone profiles near Hohenpeissenberg relative to the tropopause are shown together in Figure 3. Figure 3 reveals a layer of about $3.5-\mathrm{km}$ thick with high degree of fluctuation in ozone concentration just above the tropopause. Clearly, the S-shape ozone profile in May is a manifestation of ozone enhancement in the layer during late winter and spring, an interesting well known feature in the springtime ozone vertical distribution in the lower stratosphere [e.g., Logan, 1999b, and references therein]. We suspect that this feature is related to winter polar vortex breakdown and subsequent quasi-isentropic transport in the lowermost stratosphere. A similar feature of the springtime S-shape ozone profile is evident in the November data pair comparison at Lauder (not shown). The overall SAGE II and ozonesonde data pair comparison indicates that the annual median pair differences are within $10 \%$ above the 11-km altitude for SAGE II measurements at Hohenpeissenberg and above $10 \mathrm{~km}$ at Lauder. Below $10 \mathrm{~km}$, the SAGE II ozone is systematically lower than ozonesondes, and the bias reaches as much as 50\% a few kilometers below the tropopause (not shown).

\subsection{Monthly Zonal Median Ozone Climatology}

\subsubsection{Latitude-Height Distributions}

[15] The monthly zonal median ozone climatology at the northern midlatitudes is presented in Figure 4. Because of the large uncertainties and low ozone value bias of the SAGE II ozone measurements below the tropopause, particularly in the lower troposphere, only the ozone analyses above $8 \mathrm{~km}$ are shown. The latitudinal ozone distributions more or less follow the tropopause, with the highest gradient across the tropopause in March-April and lowest gradient in September-October-November (SON). Further discussions on the gradient in ozone across the tropopause will be shown later in subsections 3.2.2 and 3.4. In the LS, the vertical ozone gradient is higher at low latitudes than at high latitudes. Figure 4 also reveals a downward-andequatorward spread of ozone in the LS during DecemberApril. In the UT, the midlatitude ozone concentration is highest in June-July-August (JJA) and is lowest in December-January-February (DJF). The monthly ozone climatology at the southern midlatitudes is shown in Figure 5. The seasonal characteristics of the southern ozone climatology are generally similar to those of its northern counterpart. The derived monthly ozone climatology, the associated 16 th and 84th percentile values, and the auxiliary meteorological information, including air density, temperature, pressure, potential temperature, thermal/dynamic tropopause height, and potential vorticity (PV), together with their standard deviations are provided as auxiliary material to the report. ${ }^{1}$

\subsubsection{Monthly Ozone Evolution at Constant Latitude}

[16] The monthly ozone evolutions at nine latitudes between $25^{\circ} \mathrm{N}$ and $65^{\circ} \mathrm{N}$ are displayed in Figure 6. In the LS and near the tropopause, the ozone evolution exhibits an annual oscillation generally featuring the highest ozone in early spring and lowest ozone in late summer at a constant altitude. Equatorward of $45^{\circ} \mathrm{N}$, the ozone vertical gradient in the LS above the tropopause $+2 \mathrm{~km}$ is highest in August-September and lowest in February-April. Poleward of $45^{\circ} \mathrm{N}$, the vertical gradient is smallest in JuneJuly. Poleward of $35^{\circ} \mathrm{N}$, the ozone vertical gradient at and near the tropopause is the greatest in March and smallest in August, which is opposite to the situation in the LS above the tropopause $+2 \mathrm{~km}$. At $25^{\circ}-30^{\circ} \mathrm{N}$, the seasonal variation in the ozone vertical gradient near the tropopause appears to follow that in the LS.

[17] The wave type of ozone evolution follows more or less the wave type of the tropopause (Figure 6). Interestingly, the crossing between the tropopause and ozone contours is also evident. Note that, at $40^{\circ} \mathrm{N}$, the ozone 140 -ppbv contour crosses the tropopause from the LS into the UT in March, and crosses the tropopause from the UT into the LS in September, resulting in higher UT ozone in March-August than in October-February. This high summer UT ozone is consistent with the ozonesonde data studies of Logan [1999a, see also 1985], who showed a broad summer maximum in ozone at the tropopause and immediately below over Europe, the United States, and northern Japan. This summer UT ozone enhancement could be either due to tropospheric photochemistry, or STE, or a

${ }^{1}$ Auxiliary material data sets are available at $\mathrm{ftp} / / \mathrm{ftp}$.agu.org/apend/jd/ 2005jd006108. Other auxiliary material files are in the HTML. 


\section{SAGE II and Ozonesonde Data Comparison : (1984-2005)}
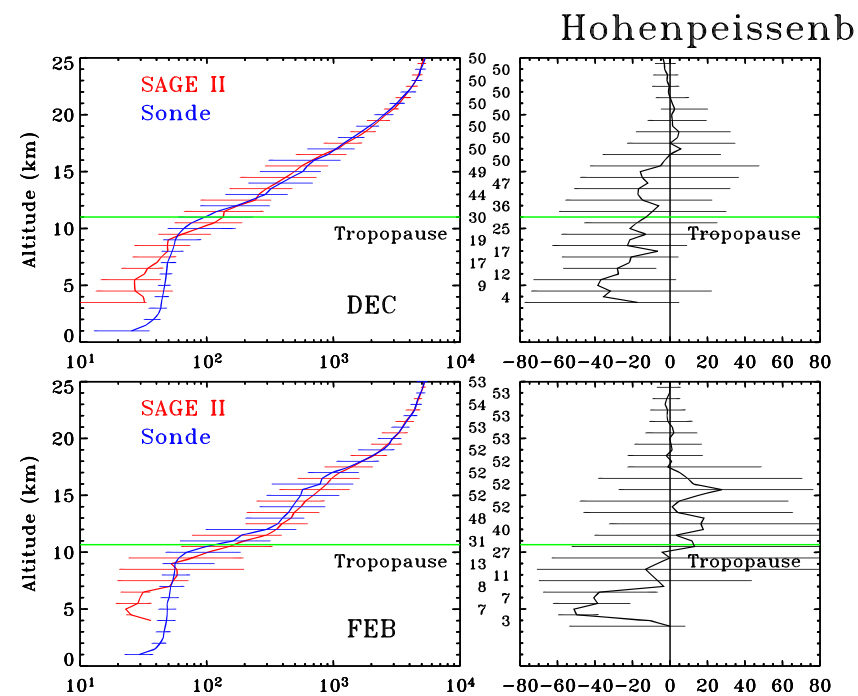

.

erg $(47.4 \mathrm{~N}, 11 \mathrm{E})$
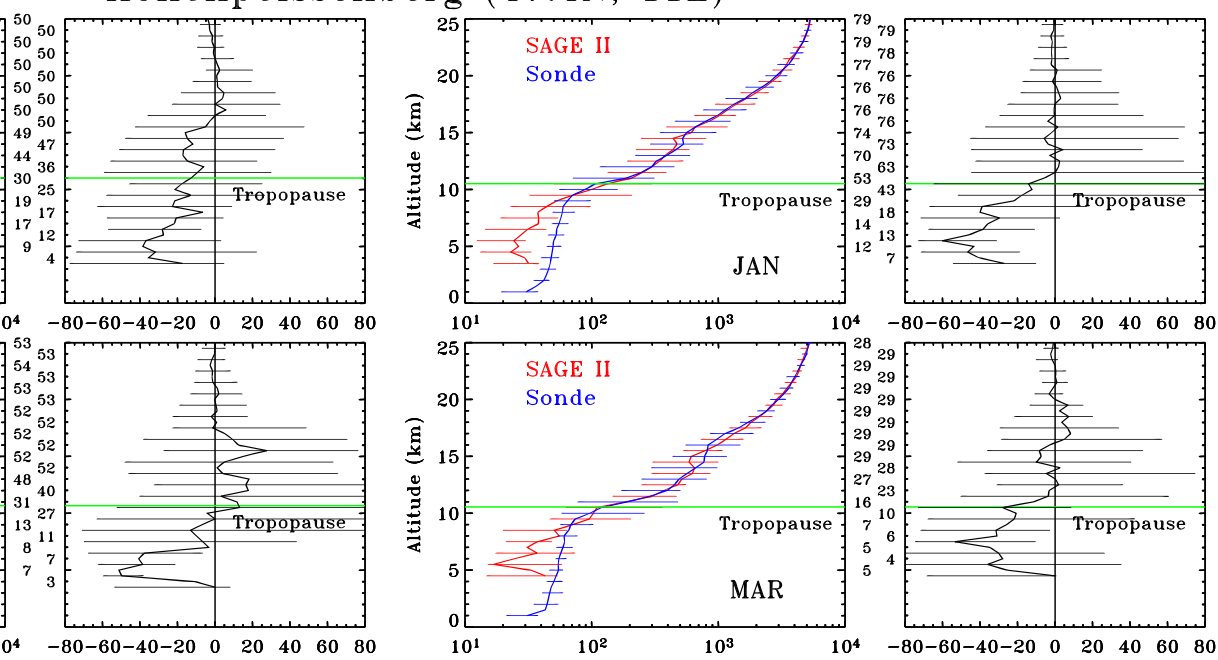

$-80-60-40-20 \quad 0 \quad 20 \quad 40 \quad 60 \quad 80$

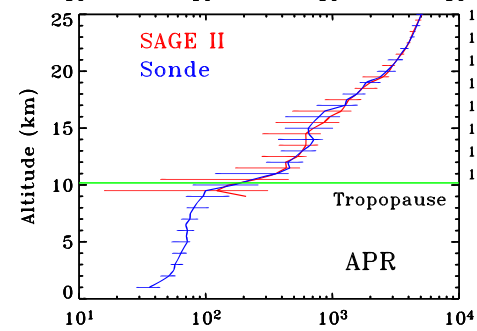

$\begin{array}{lllllll}0^{4} & -80-60-40-20 & 0 & 20 & 40 & 60 & 80\end{array}$

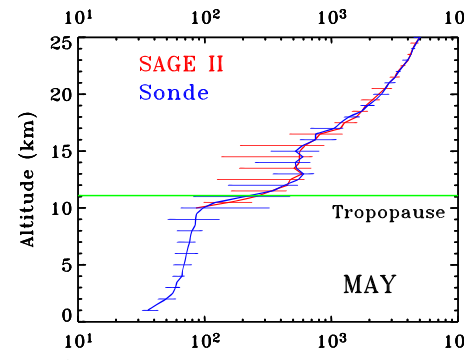

$\begin{array}{lllllll}4 & -80-60-40-20 & 0 & 20 & 40 & 60 & 80\end{array}$
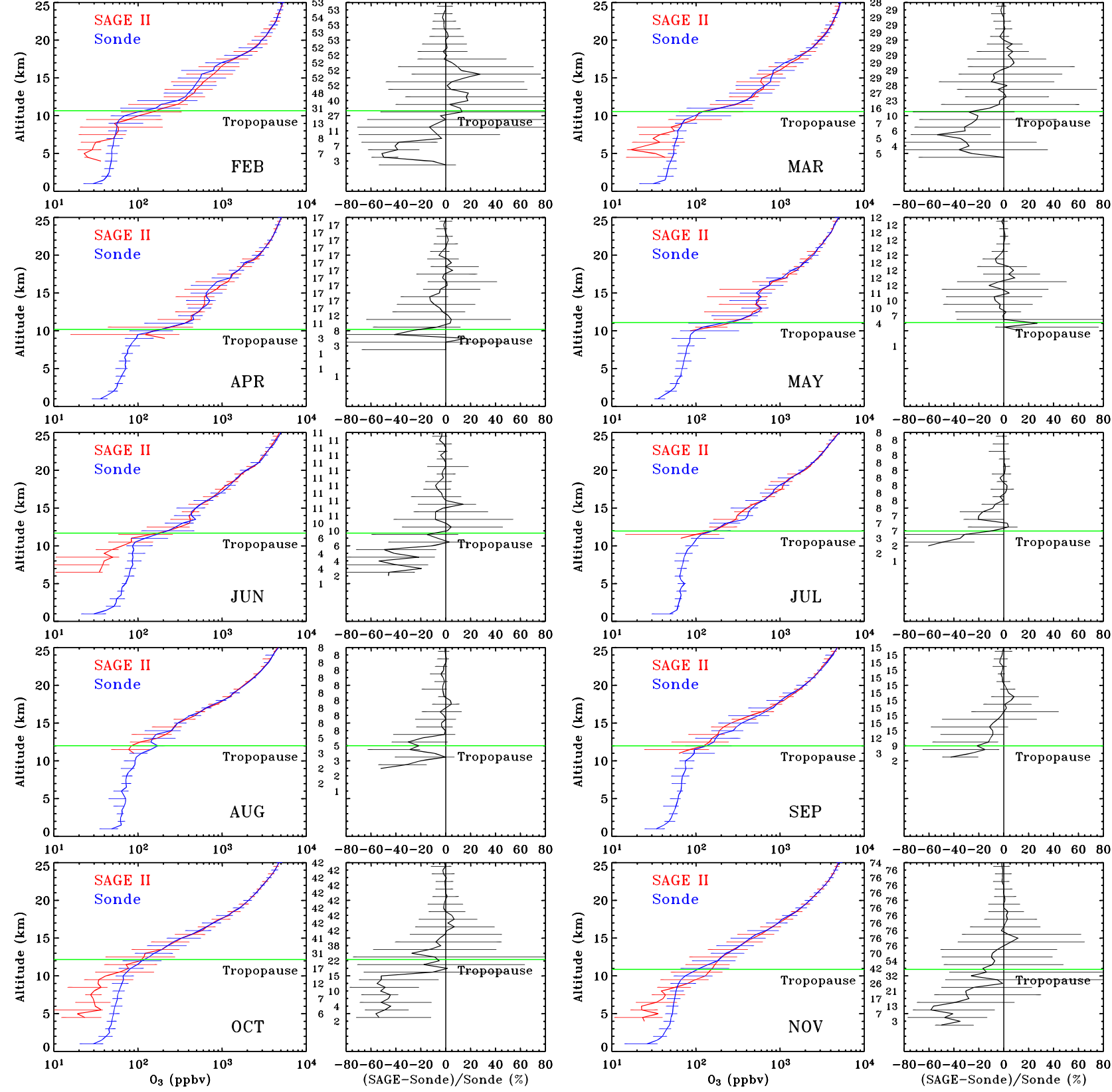

Figure 2. SAGE II and coincident Hohenpeissenberg $\left(47.4^{\circ} \mathrm{N}, 11^{\circ} \mathrm{E}\right)$ ozonesonde monthly data pair comparisons. SAGE II medians are in red and the ozonesonde medians are in blue. The horizontal bars indicate the associated uncertainties in the medians. The differences between SAGE II and ozonesonde are shown to the right of the ozone median profile. The numbers between the ozone median and the ozone difference indicate the sample size. The ozone difference is given as median of (SAGE-Sonde)/ Sonde in \%. The horizontal bar in green indicates the location of the tropopause. 


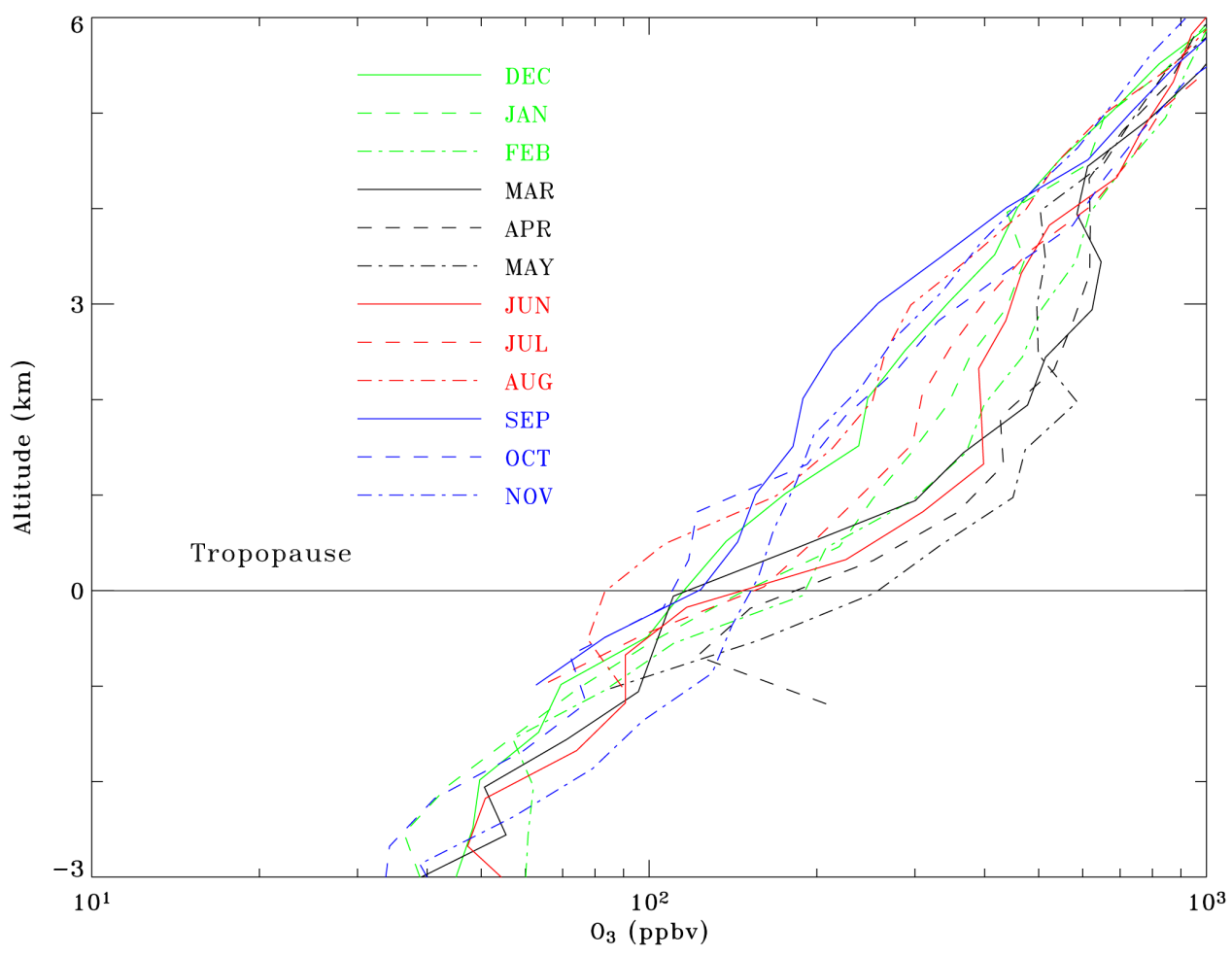

Figure 3. A composite plot of the SAGE II monthly median ozone mixing ratio profiles near Hohenpeissenberg $\left(47.4^{\circ} \mathrm{N}, 11^{\circ} \mathrm{E}\right)$ shown in Figure 2 relative to the tropopause.

combination of the two. The monthly ozone evolutions at southern midlatitudes are shown in Figure 7. The seasonal variations in the LS ozone vertical gradient, the wave type of ozone evolution, and the crossing between the tropopause and ozone contours are generally similar to those at the northern midlatitudes (Figure 6).

\subsection{Zonal Median Ozone Near Hohenpeissenberg and Lauder}

[18] The monthly evolution of the zonal median ozone in the midlatitude UTLS from SAGE II is compared with that of the ozonesonde measurements at Hohenpeissenberg and Lauder in Figure 8. Despite the fact that the ozonesonde data are measurements from single stations, the SAGE II zonal medians (Figures $8 \mathrm{a}$ and $8 \mathrm{~b}$ ) and the ozonesonde data (Figures $8 \mathrm{c}$ and $8 \mathrm{~d}$ ) reveal generally similar monthly ozone evolution in the UTLS. Note, the greatest ozone vertical gradient near the tropopause in late winter through early summer, the greatest ozone vertical gradient at altitudes above the tropopause $+2 \mathrm{~km}$ in late summer and early autumn, and the highest ozone concentration around the tropopause in summer.

[19] Shown also in Figure 8 are the monthly ozone variabilities from SAGE II and ozonesonde. The resemblance in ozone variability between SAGE II and ozonesonde is less evident than in their monthly ozone evolutions. The reason for this difference is likely due to the fact that SAGE II results are derived from zonal data sets while the results from ozonesondes are medians from single stations. Thus the SAGE II analysis involves zonal variability. This is not the case for the ozonesondes. Nevertheless, high ozone variability in the northern UTLS during winter and spring months is evident (Figures 8a and $8 \mathrm{c}$ ), consistent with the ozonesonde data analysis of Logan [1999b]. In the southern UTLS, while the SAGE II observations reveal high ozone variability during February (Figure 8b), the Lauder ozonesonde data reveal no clear seasonal feature, except the low ozone variability in the UT during April-June (Figure 8d).

\subsection{Tropopause Ozone at Midlatitudes \\ 3.4.1. Monthly Evolution}

[20] Following the investigation of Logan [1999a], we have studied the monthly latitudinal distributions of zonal median ozone at the tropopause, $2 \mathrm{~km}$ above tropopause, and $1 \mathrm{~km}$ below tropopause. The results of the monthly ozone evolution and the monthly evolution of the tropopause height are shown in Figure 9. In the $\mathrm{NH}$, the tropopause is lowest in February and highest in August (Figure 9a), while the tropopause ozone generally increases from January to June and declines from July to December (Figure 9c). With respect to the ozone peak at low latitudes, there is a delay in the occurrence of the tropopause ozone maximum at high latitudes by about $1-1.5$ months (Figure 9c). No such delay is shown in the tropopause height (Figure 9a). The summer ozone maximum near $60^{\circ} \mathrm{N}$ is also shown in the ozonesonde data analysis for $40^{\circ} \mathrm{N}-$ $75^{\circ} \mathrm{N}$ of Logan [1999a].

[21] At southern midlatitudes, the tropopause height reveals seasonal variations similar to those at northern midlatitudes (Figures 9a and 9e). This is not the case for the tropopause ozone. The tropopause ozone maximum appears first at southern high latitudes in late winter (Figure 9g), in contrast to the situation at the northern midlatitudes, where the tropopause ozone maximum occurs first at about $40^{\circ} \mathrm{N}$ in spring (Figure 9c). In addition, with 


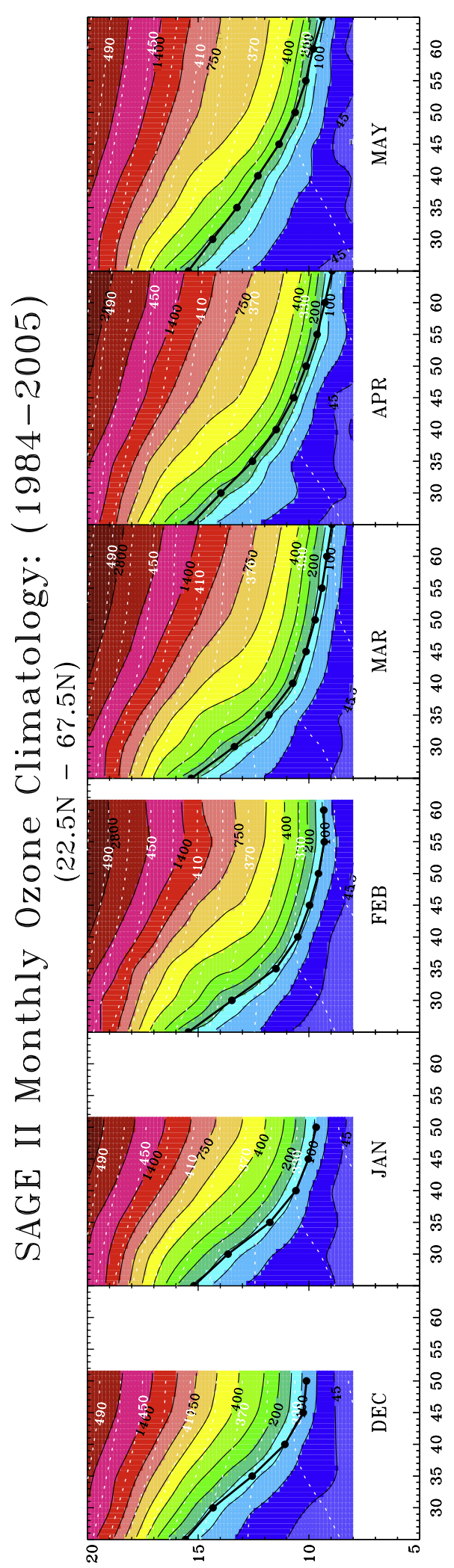

(uу) әрnา!วIV

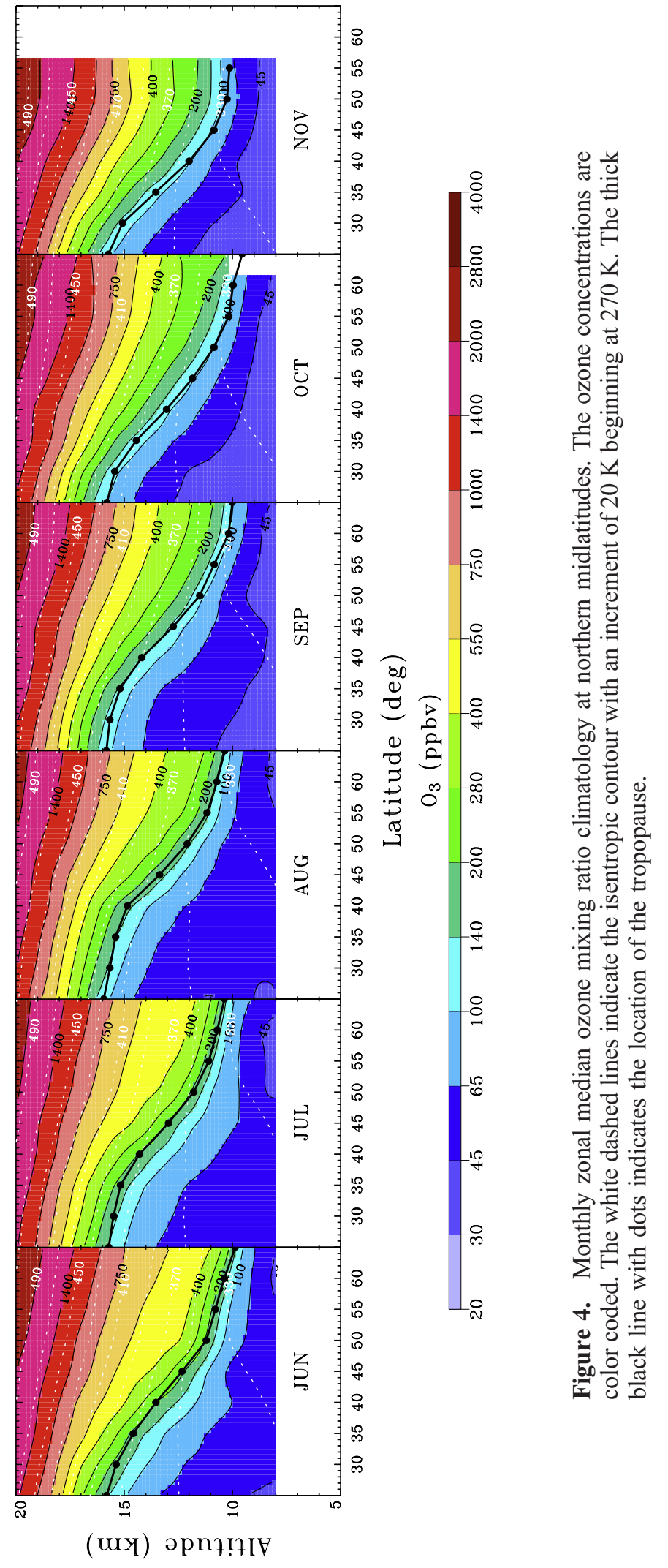



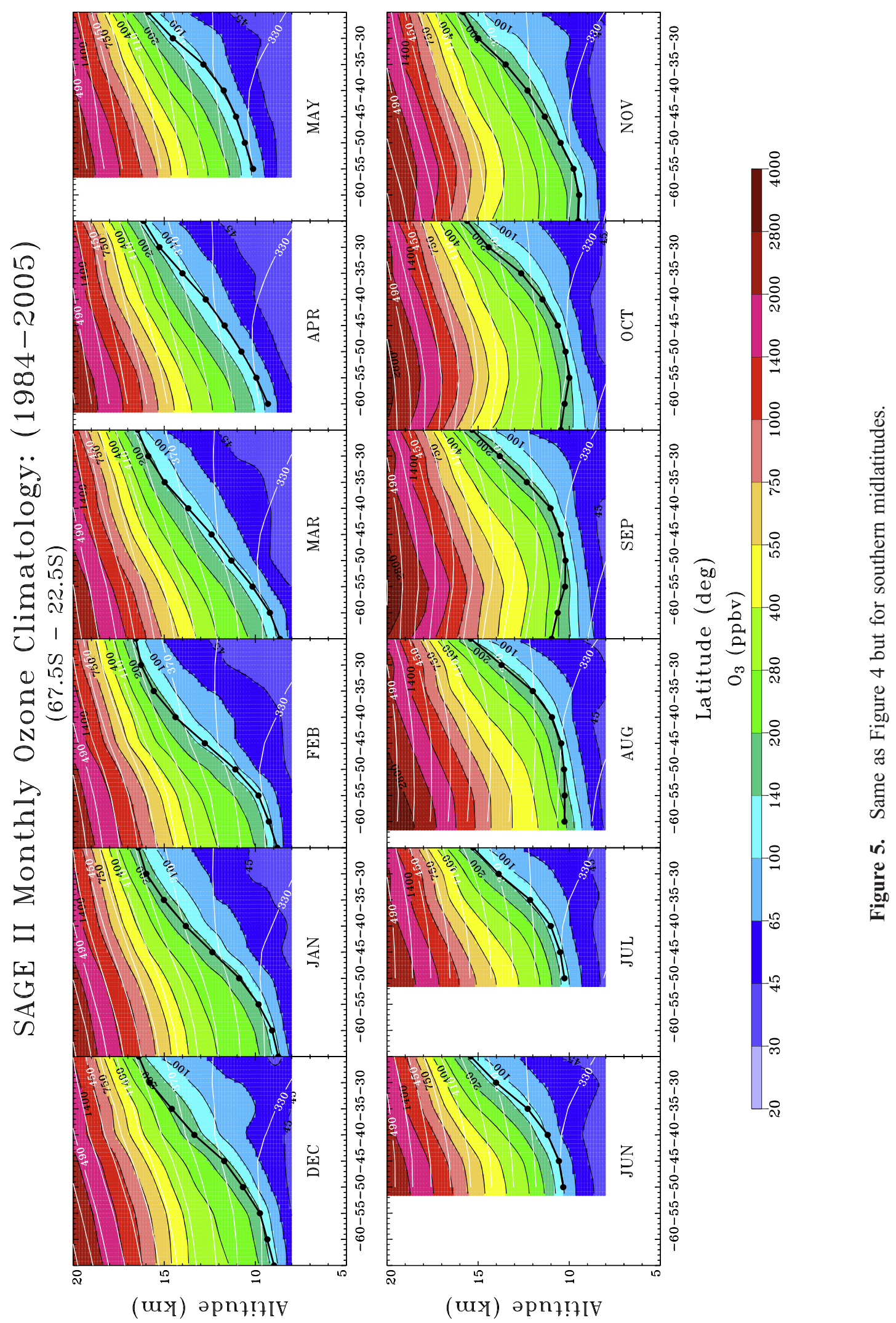


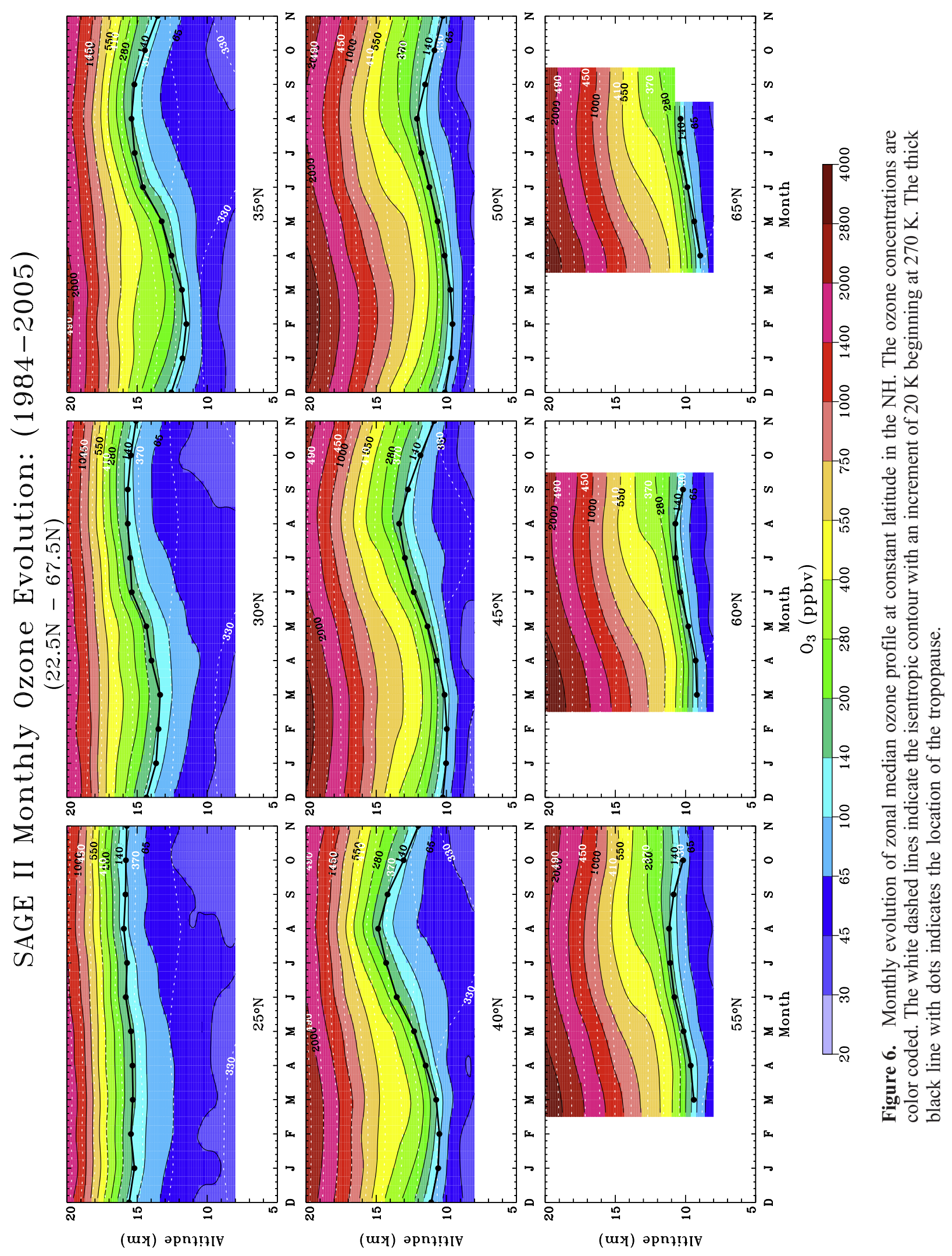




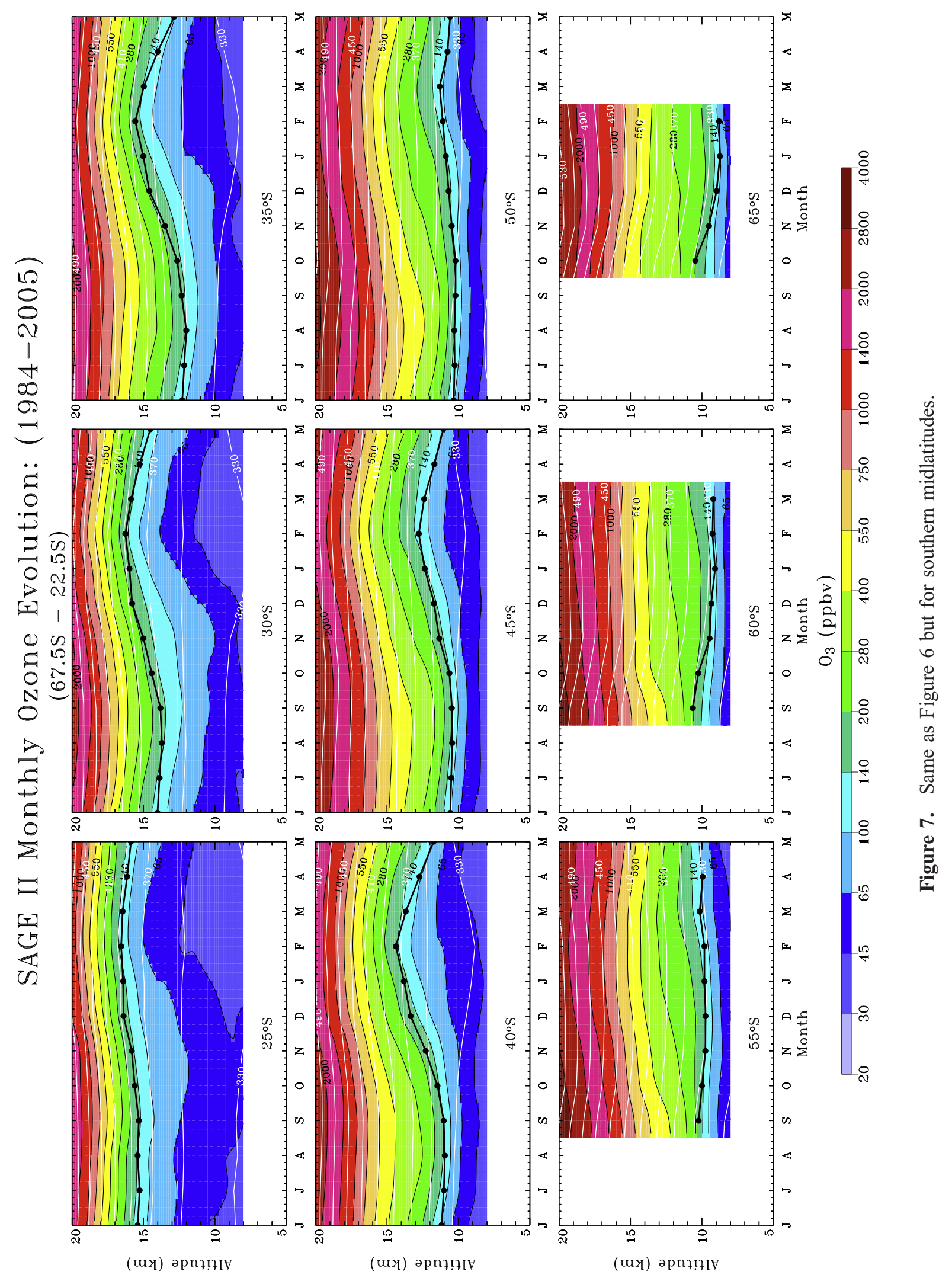




\section{SAGE II and Ozonesonde Data Analysis}

(a) SAGE II $(47.4 \mathrm{~N} \pm 2.5$ 1984-2005)
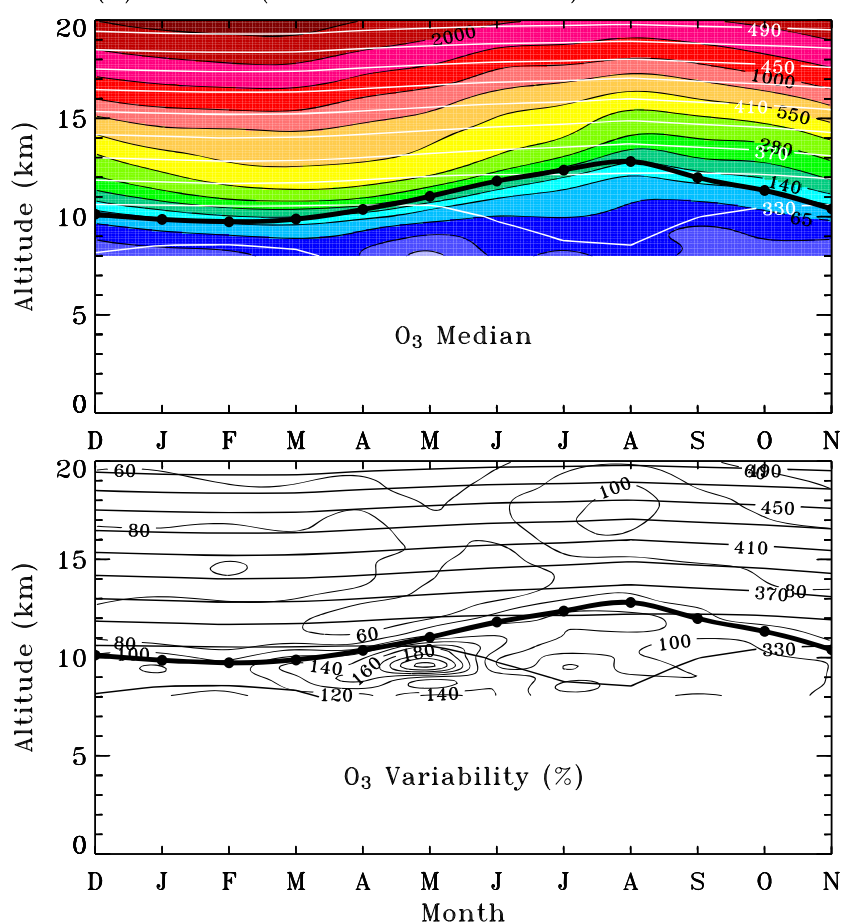

(b) SAGE II $(45.0 \mathrm{~S} \pm 2.5 \quad 1984-2005)$
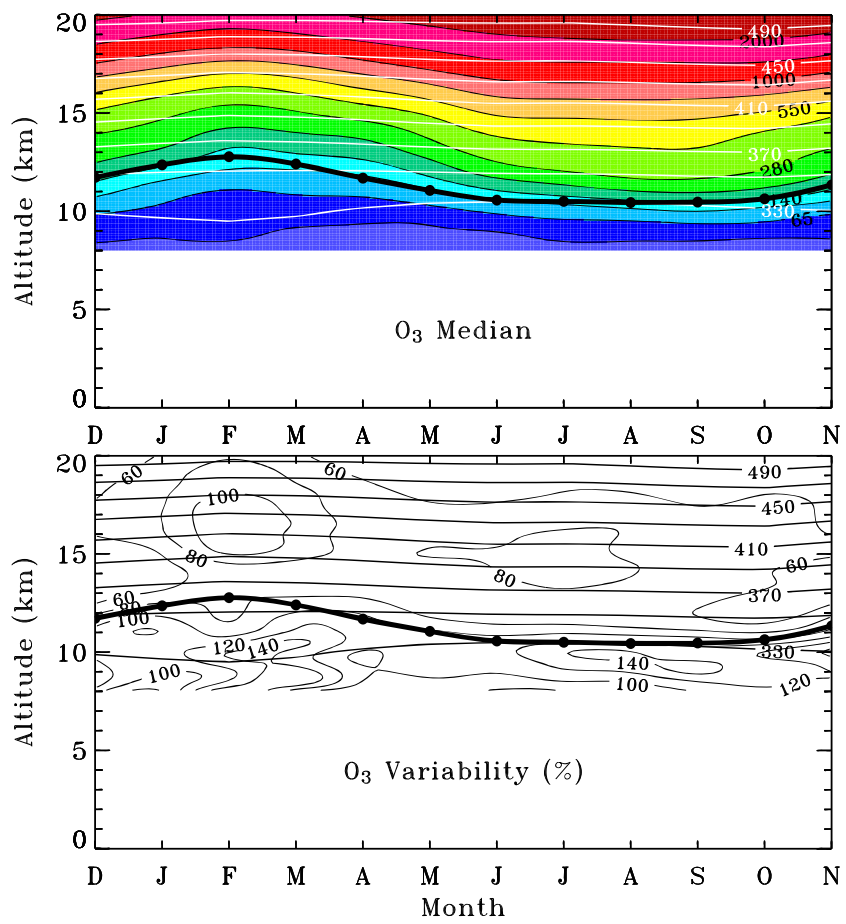

(c) Hohenpeissenberg $(47.4 \mathrm{~N}, 11 \mathrm{E}), 1985-2005$
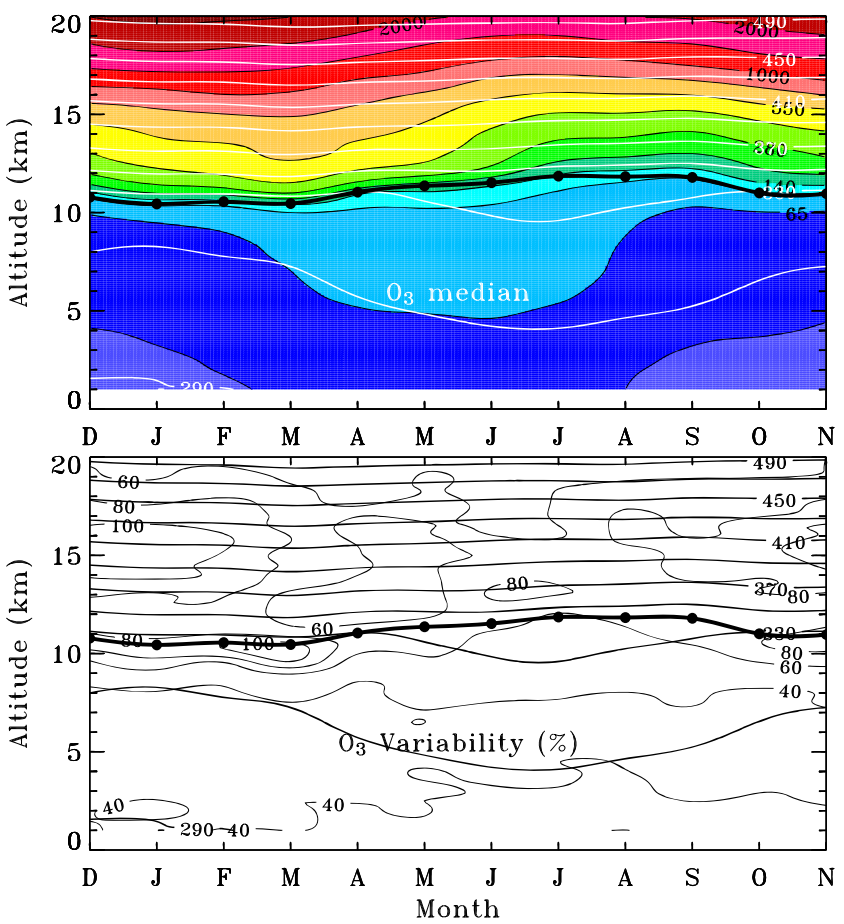

(d) Lauder (45S, 169.7E), 1986-2005
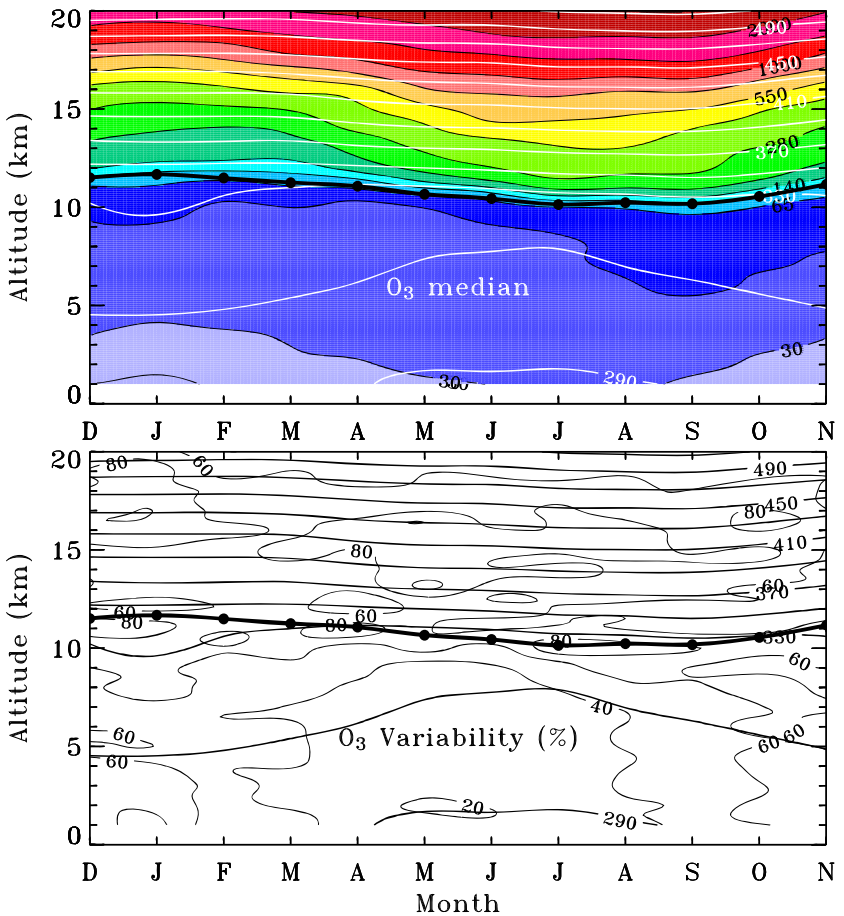

$\mathrm{O}_{3}(\mathrm{ppbv})$

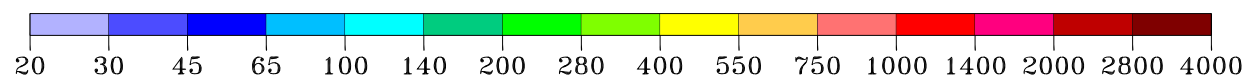

Figure 8. Annual cycle of SAGE II monthly zonal ozone median and associated variability as a function of height centered at (a) $47.5^{\circ} \mathrm{N}$ and (b) $45^{\circ} \mathrm{S}$. Monthly ozonesonde median and associated variability as a function of height at (c) Hohenpeissenberg $\left(47.4^{\circ} \mathrm{N}, 11^{\circ} \mathrm{E}\right)$ and (d) Lauder $\left(45^{\circ} \mathrm{S}\right.$, $169.7^{\circ} \mathrm{E}$ ). The ozone mixing ratios are color coded. The thick line with dots indicates the tropopause, and the dashed lines are the potential temperature contours with an increment of $20 \mathrm{~K}$ beginning at $270 \mathrm{~K}$. 
Monthly Evolution of Tropopause Height: (1984-2005)
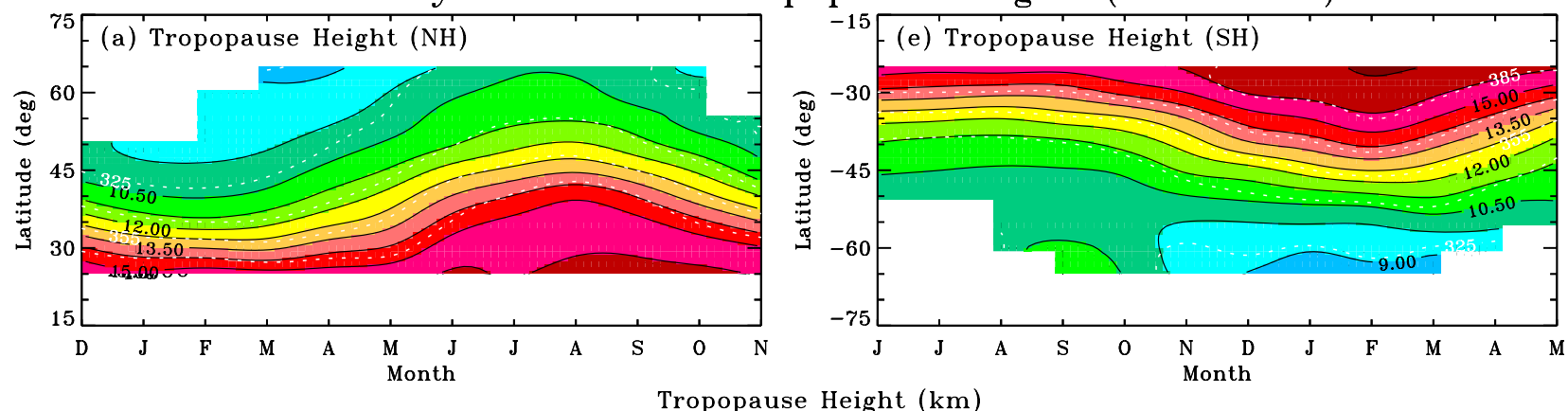

Tropopause Height $(\mathrm{km})$

$\begin{array}{llllllllllllllll}6.00 & 6.75 & 7.50 & 8.25 & 9.00 & 9.75 & 10.50 & 11.25 & 12.00 & 12.75 & 13.50 & 14.25 & 15.00 & 15.75 & 16.50 & 17.25\end{array}$

Ozone Relative to Tropopause: (1984-2005)
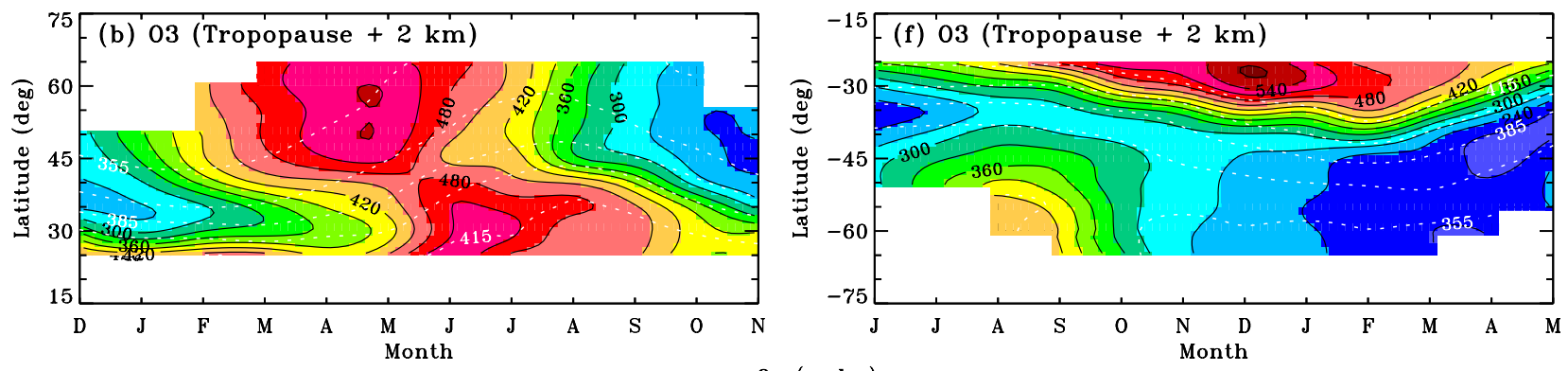

$\mathrm{O}_{3}(\mathrm{ppbv})$
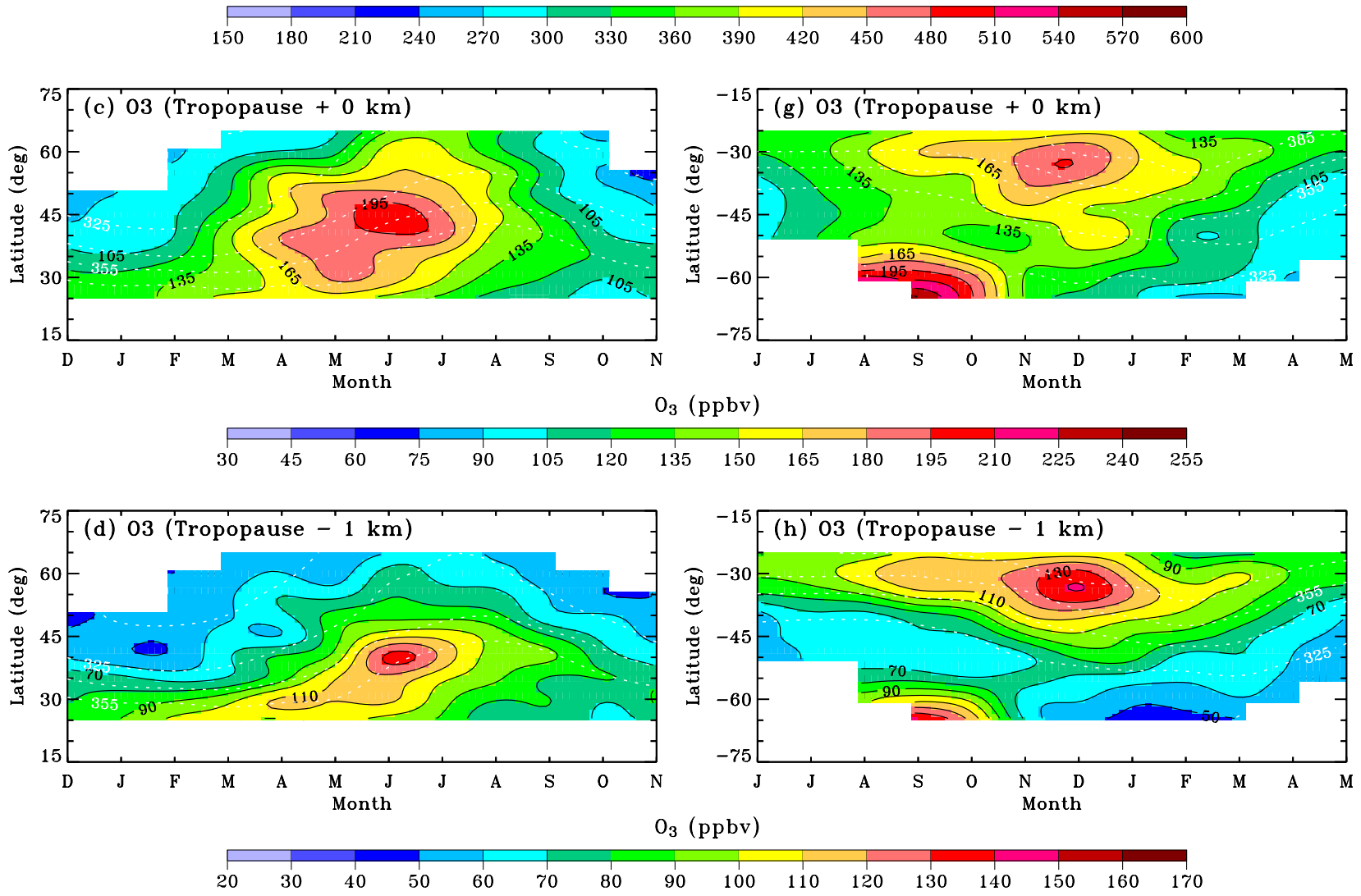

Figure 9. Monthly evolution of the northern midlatitude (a) tropopause height and zonal median ozone at (b) tropopause plus $2 \mathrm{~km}$, (c) the tropopause, and (d) tropopause minus $1 \mathrm{~km}$. Monthly evolution of the Southern midlatitude (e) tropopause height and zonal median ozone at (f) tropopause plus $2 \mathrm{~km},(\mathrm{~g})$ the tropopause, and (h) tropopause minus $1 \mathrm{~km}$. The ozone mixing ratios are color coded. The white dashed lines indicate the isentropic contours with an increment of $15 \mathrm{~K}$ beginning at $280 \mathrm{~K}$. 
respect to the southern high-latitude ozone maximum, there is a 2-3 month delay in the occurrence of the ozone maximum at $30^{\circ} \mathrm{S}$ (Figure $9 \mathrm{~g}$ ). At $1 \mathrm{~km}$ below the tropopause, the ozone evolution generally exhibits similar characteristics to that at the tropopause in both hemispheres (Figures 9c, 9d, 9g, and 9h). Logan [1999a] showed enhanced tropopause ozone in November-January and reduced ozone in March-June in Lauder ozonesonde data. A similar feature is evident at $45^{\circ} \mathrm{S}$ (Figure $9 \mathrm{~g}$ ).

[22] At the altitude of $2 \mathrm{~km}$ above the tropopause, the ozone at northern high latitudes (poleward of $40^{\circ} \mathrm{N}$ ) peaks in April-May and minimizes in October-November (Figure 9b). Such a monthly ozone evolution is also consistent with that derived from four Canadian ozonesonde stations [Logan, 1999a]. Equatorward of $35^{\circ} \mathrm{N}$, the ozone increases from December to June. In addition, there is a positive ozone gradient toward the tropics during the same period. From May to July, the ozone gradient diminishes concurrently with a rapid increase in ozone in early summer. During the late summer and fall, ozone declines at northern low latitudes. In the $\mathrm{SH}$, the ozone also peaks in early summer and minimizes in winter at low latitudes; it maximizes in early spring and minimizes in early fall at high latitudes (Figure 9f). However, the spring ozone enhancement at southern high latitudes and the summer peak at southern low latitudes are less intense than their northern counterpart. While the occurrence of the late spring ozone peak at high latitudes can be related to downward spread of ozone-rich air in the lowermost stratosphere, the lowlatitude ozone maximum during summer is most likely due to summer photochemical ozone production. Another distinct difference between the $\mathrm{NH}$ and $\mathrm{SH}$ is in the vertical structure of the monthly ozone evolution. In the $\mathrm{NH}$, the ozone evolution at the tropopause and below is quite different from that in the LS (tropopause $+2 \mathrm{~km}$ ) (Figures 9b-9d) [see also Logan, 1999a]. In contrast, the ozone annual cycle at the tropopause and below resembles to some extent that at $2 \mathrm{~km}$ above the tropopause in the southern LS, as shown in Figures $9 \mathrm{f}-9 \mathrm{~h}$.

[23] In Figure 9, we have seen interesting ozone properties in terms of ozone distributions relative to the thermal tropopause. It would also be useful to investigate ozone distributions relative to the dynamic tropopause according to the potential vorticity of $2.5 \mathrm{PVU}\left[(\mathrm{K} / \mathrm{sec})\left(\mathrm{m}^{2} / \mathrm{kg}\right)\right]$ (referred to as PV tropopause hereafter to distinguish from the conventional tropopause, i.e., the thermal tropopause). The results of this investigation are shown in Figure 10. First of all, the PV tropopause is located at a lower altitude than the thermal tropopause (Figures 9a and 9e) by about $2 \mathrm{~km}$ at low latitudes and by about $1 \mathrm{~km}$ at high latitudes, leading to a lower degree of the latitudinal gradient of the dynamic tropopause height than of the thermal tropopause. Since PV is conservative for adiabatic processes, changes in ozone at the PV tropopause suggest diabatic, photochemical production, and isentropic STE processes. From Figure 10, we see ozone changes associated with seasonal changes in the large-scale diabatic circulation in the LS with ozone enhancement poleward of $40^{\circ}$ in winter through spring and ozone decrease in summer and autumn (Figures $10 \mathrm{~b}$ and 10f). At the PV tropopause and PV tropopause $-1 \mathrm{~km}$, Figure 10 shows ozone enhancement between late winter and summer, particularly at latitudes equatorward of $45^{\circ}$
(Figures 10c-10h), likely related to ozone photochemical production and isentropic STE. In terms of the ozone vertical structure, both the $\mathrm{SH}$ and the $\mathrm{NH}$ reveal a different monthly ozone evolution at the PV tropopause $+2 \mathrm{~km}$ from that at the PV tropopause and below (Figures 10b-10d and $10 \mathrm{f}-10 \mathrm{~h}$ ).

\subsubsection{Effect of Vertical Tropopause Displacement}

[24] To examine the induced ozone change due solely to vertical displacement of the tropopause, we assume that the ozone profile remains the same from one month to the next. An example of the analysis is shown in Figure 11a for the period from May to June at $45^{\circ} \mathrm{N}$. In Figure $11 \mathrm{a}$, the horizontal distance between points $\mathrm{A}$ and $\mathrm{B}$ equals the induced ozone change, and the horizontal distance between points $\mathrm{A}$ and $\mathrm{C}$ equals the observed ozone change. The difference in ozone change between the observed and the induced ozone changes is indicated by the horizontal distance between the two points $\mathrm{B}$ and $\mathrm{C}$ in Figure 11a. A more detailed comparison for the midlatitude band between $25^{\circ}$ and $50^{\circ}$ is presented in Figure $11 \mathrm{~b}$. The monthly characteristics of the observed ozone change are quite different from those of the induced ozone change. The maximum and minimum tropopause ozone changes derived from SAGE II data lead respectively the maximum and minimum tropopause ozone changes induced by the tropopause change by about two months in the NH and by three months in the SH. Thus changes in tropopause height alone cannot satisfactorily explain the observed annual cycle of the midlatitude tropopause ozone. Additional mechanism(s) must be involved in controlling the tropopause ozone.

\subsubsection{Seasonal Longitude-Latitude Tropopause Ozone Distribution}

[25] To add to the understanding of the tropopause ozone behavior, the seasonal ozone longitude-latitude distributions at the tropopause are analyzed (Figure 12). The seasonal longitude-latitude distributions of tropopause ozone provide information on geographic areas that are most favorable for exchange of ozone between the tropics and the extratropics and between the $\mathrm{NH}$ and the $\mathrm{SH}$, in addition to the seasonal dependence of the arrival of ozone from the LS and UT. Wang et al. [2002] showed that the mean difference between SAGE II and collocated ozonesondes is about 5-20\% near the tropopause in the tropics.

[26] In general, Figure 12 exhibits low tropopause ozone in the tropics and high tropopause ozone in the extratropics, consistent with the general concept that the large-scale circulation features upward motion in the tropics and descent at middle and high latitudes [Rosenlof, 1995], given the fact that the ozone concentration is higher in the stratosphere than in the troposphere. Note the low tropopause ozone concentrations over the western tropical Pacific and northern South America. These are regions where deep convection is prevalent. Studies using SAGE II water vapor data also indicated low water vapor over these areas in the LS [e.g., Wang et al., 1996].

[27] In the extratropical NH, tropopause ozone increases in spring with the highest concentrations occurring over the eastern Mediterranean, China, the northern Pacific, and the northern Atlantic, and low ozone over eastern Siberia and Canada (Figure 12b). Note the sharp ozone gradient along the southern edge of the rich ozone distribution. The northern extratropical ozone distributions during winter 
Evolution of dynamic Tropopause Height: (1984-2005)
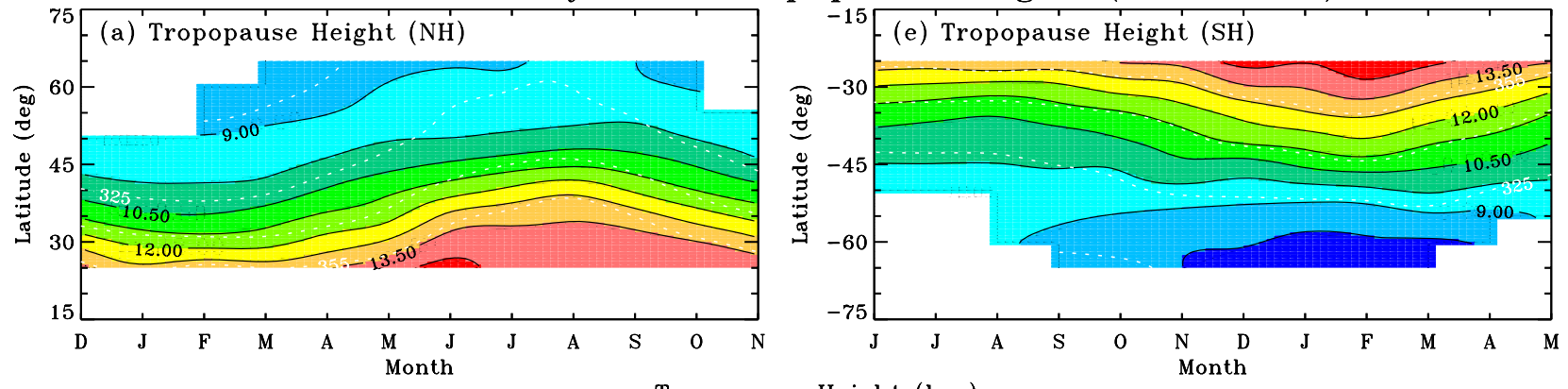

Tropopause Height $(\mathrm{km})$

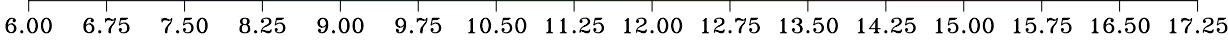

Ozone Relative to Tropopause: (1984-2005)
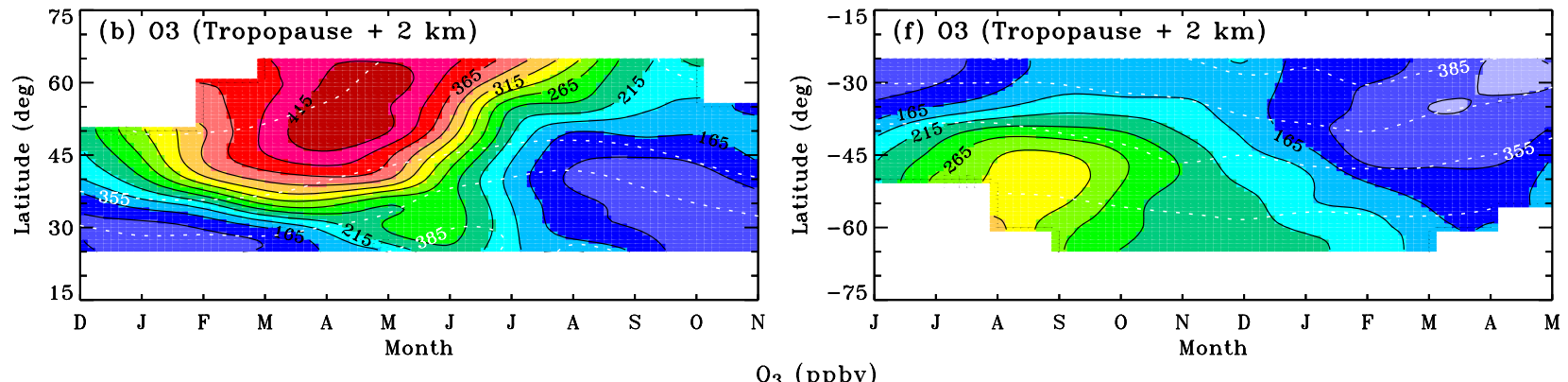

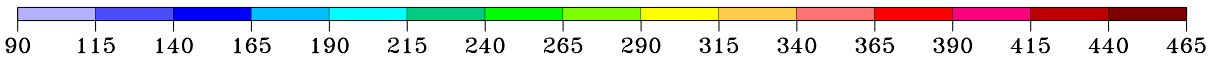
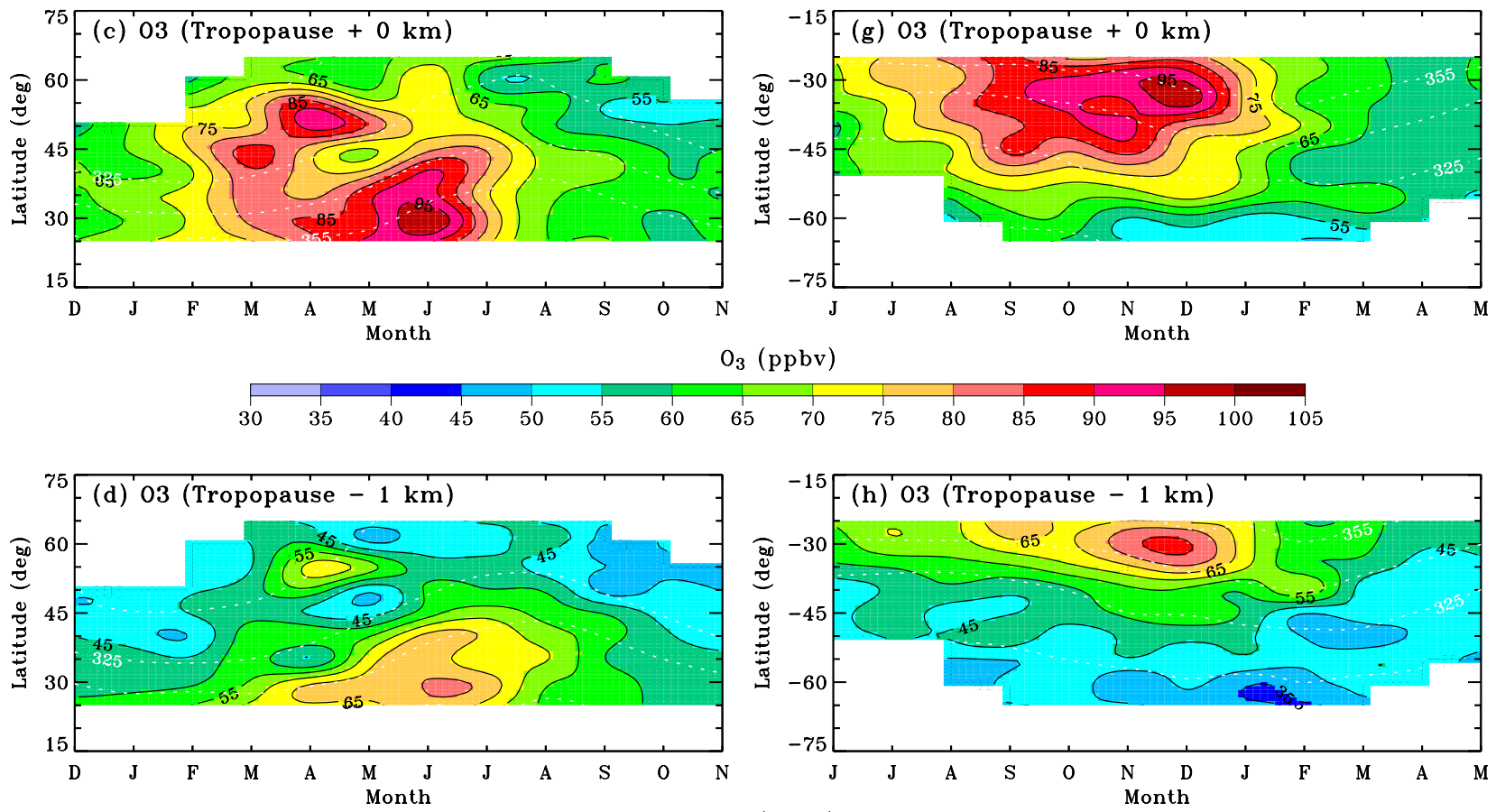

$\mathrm{O}_{3}(\mathrm{ppbv})$

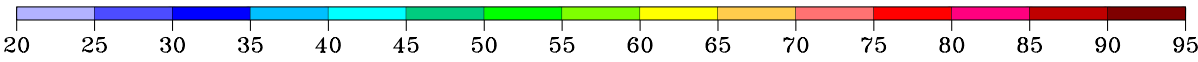

Figure 10. $(a-h)$ Same as Figure 9 but for ozone relative to the dynamical tropopause, i.e., 2.5 PVU. 
(a) Zonal median ozone mixing ratio profile $\left(45^{\circ} \mathrm{N}\right)$

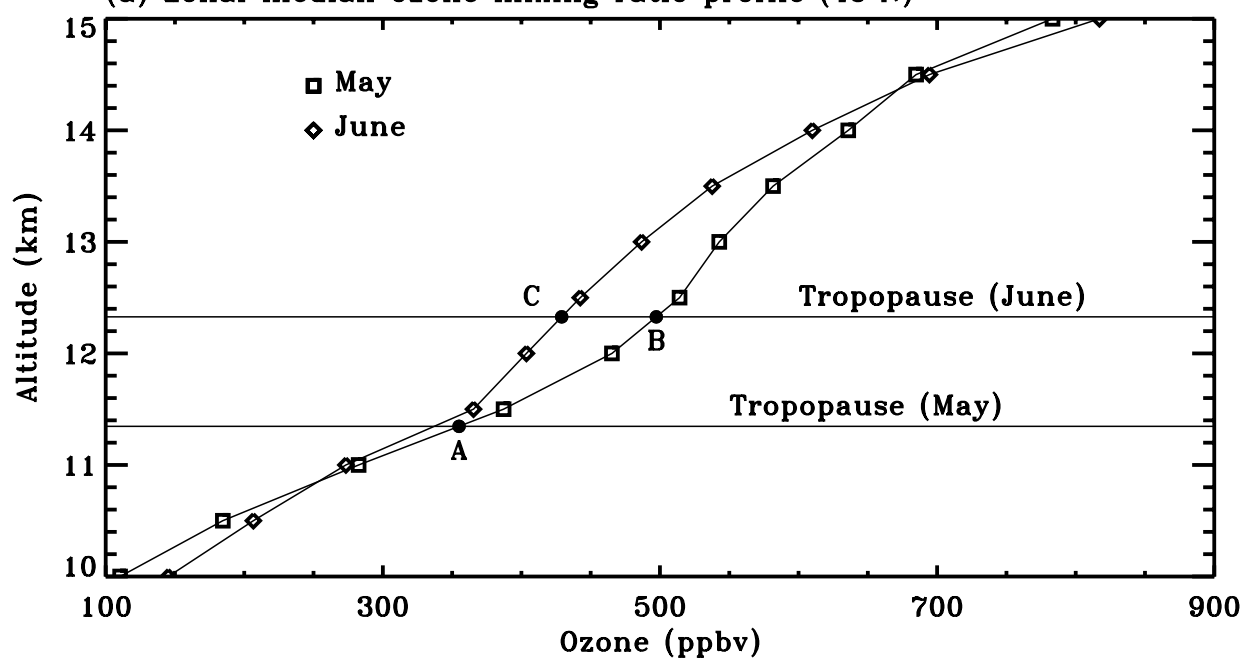

(b) Monthly ozone change at the tropopause

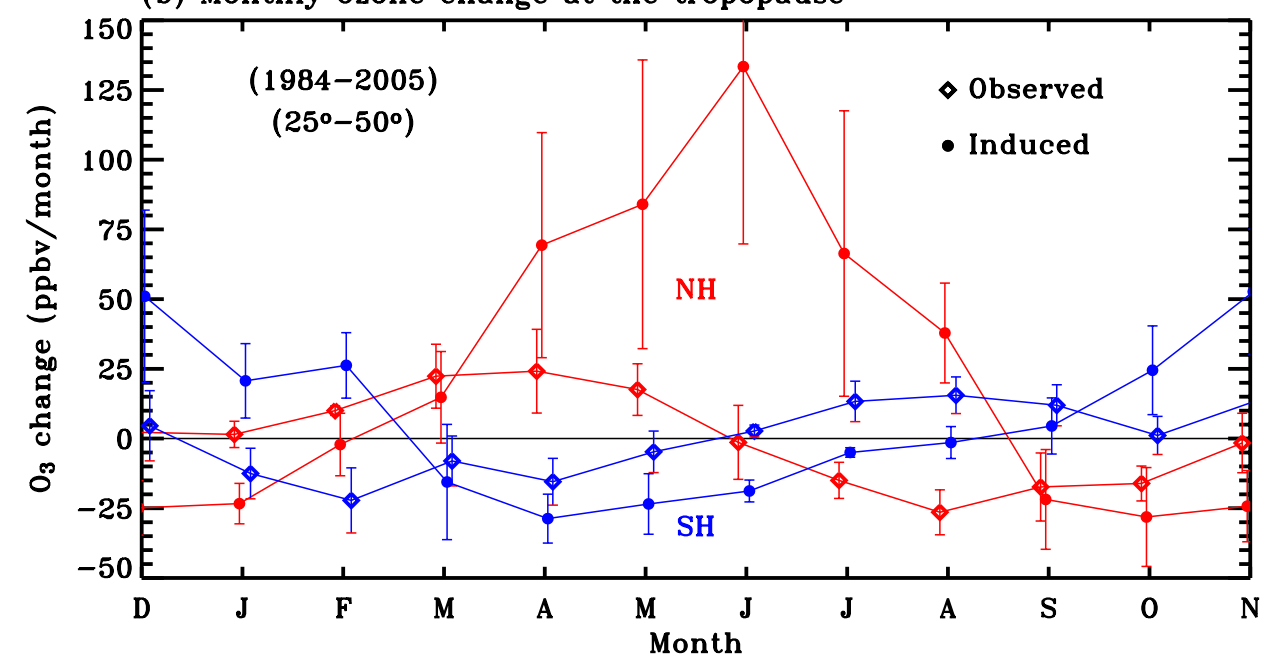

Figure 11. (a) A comparison of the monthly ozone change observed by SAGE II and the change induced by tropopause height variation at $45^{\circ} \mathrm{N}$ from May to June. Point A indicates tropopause ozone in May. The induced ozone change from May to June is indicated by the horizontal distance between $\mathrm{A}$ and B. The observed change is given by the horizontal distance between A and C. (b) Comparison of the midlatitude $\left(25^{\circ}-50^{\circ}\right)$ observed monthly change in tropopause ozone (diamonds) with the induced monthly ozone change by tropopause height changes (dots). The Northern Hemispheric results are in red, and the Southern Hemispheric results are in blue.

(Figure 12a) are generally similar to those of spring (Figure 12b) but ozone concentrations are somewhat smaller. The locations of these high ozone areas coincide generally with storm track regions and warm conveyor belts [e.g., Stohl et al., 2003a]. By summer, ozone maximizes over southwestern Europe, northeastern Asia, and the northern Pacific (Figure 12c). Note the severely distorted ozone contours $(110-155 \mathrm{ppbv})$ in the northern subtropics (Figure 12c), signifying ozone exchange between the tropics and the northern midlatitudes [e.g., Chen, 1995; Jing et al., 2004]. This feature is consistent with the high summer statistics of Rossby wave breaking [Postel and Hitchman, 1999], and monsoon activities [Dunkerton, 1995]. Note also the relatively high ozone values (95100 ppbv) over the tropical western Indian Ocean around $50^{\circ} \mathrm{E}$ as to suggest possible cross equator ozone transport from the $\mathrm{NH}$ to the $\mathrm{SH}$ in JJA. During SON, the ozone concentration in the NH decreases (Figure 12d). However, the ozone distributions over southern China, the eastern midlatitude Pacific, and the eastern midlatitude Atlantic are still higher than other regions in the NH (Figure 12d).

[28] In the extratropical $\mathrm{SH}$, the tropopause ozone seasonal variation is somewhat different from that in the NH. The tropopause ozone peaks during austral spring at high latitudes, particularly between $150^{\circ} \mathrm{W}$ and $60^{\circ} \mathrm{E}$ (Figure 12d). We see also a region of low ozone centered at about $50^{\circ} \mathrm{S}: 175^{\circ} \mathrm{E}$ southeast of Australia. Note the sharp meridional ozone gradient at $25^{\circ} \mathrm{S}$ (Figure 12d). In summer, the ozone declines at southern high latitudes concurrent with the equatorward ozone spread, which is particularly 


\section{Tropopause Ozone Seasonal Variation (1984-2005)}
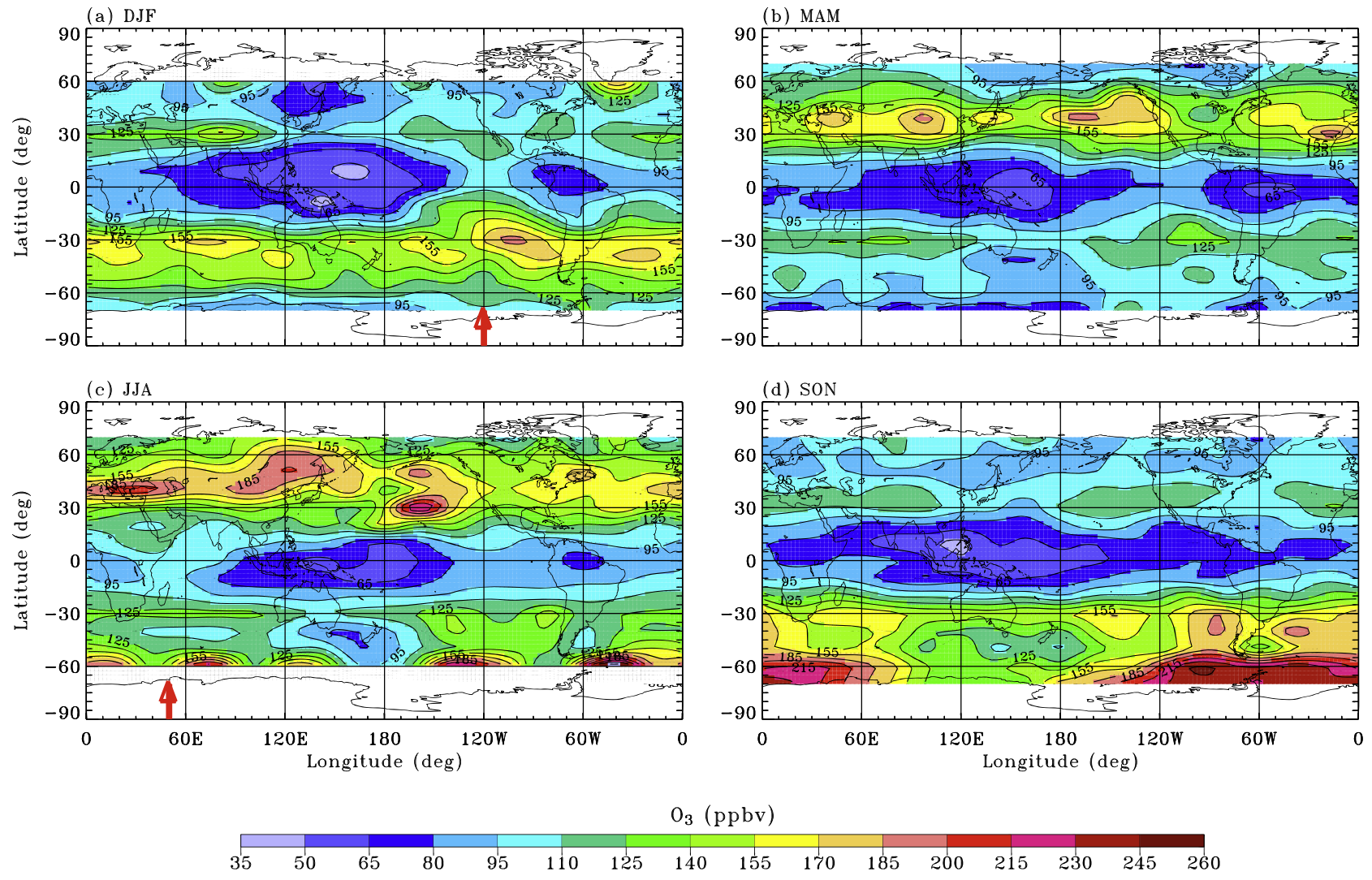

Figure 12. Seasonal longitude-latitude tropopause ozone distributions derived from the SAGE II multiyear (1984-2005) observations. (a) DJF, (b) MAM, (c) JJA, and (d) SON. Ozone mixing ratios are color coded. The thick red arrow in Figures $12 \mathrm{a}$ and $12 \mathrm{c}$ indicates the potential region for interhemispherical ozone exchange in the tropics.

evident over the subtropical Eastern Pacific (Figure 12a), resulting in a pattern that resembles the model study of Chen [1995]. Furthermore, the ozone concentrations around $120^{\circ} \mathrm{W}$ are higher than in other regions in the tropics (Figure 12a). This feature suggests interhemispheric ozone exchange from the $\mathrm{SH}$ to the $\mathrm{NH}$ through isentropic transport and mixing during DJF. The tropopause ozone in the $\mathrm{SH}$ also reaches its lowest level in austral autumn (Figure 12b), followed by an enhancement in winter (Figure 12c).

\subsubsection{Tropopause Ozone PDFs}

[29] Examination of the monthly ozone PDF permits detailed insight into the growth and decay of a spectrum of ozone concentrations at the tropopause, thus enabling us to explore the arrival and departure of ozone-rich/ozonepoor air at the tropopause and the timing associated with stratosphere to troposphere transport (STT) and troposphere to stratosphere transport (TST). The present PDF study covers a range of ozone mixing ratios up to $540 \mathrm{ppbv}$ using a bin width of 30 ppbv.

[30] The area normalized monthly ozone PDFs at northern midlatitudes $\left(45^{\circ} \mathrm{N}-50^{\circ} \mathrm{N}\right)$ are presented in Figure $13 \mathrm{a}$. The shape of the PDFs is not Gaussian. During NovemberFebruary, the PDFs feature a peak in the 60-90 ppbv bin. Beginning in March, the probability for ozone concentrations greater than about 120 ppbv gradually increases. The growth of the probability in these high ozone concentration bins continues into June, indicating the arrival of ozone-rich air at the tropopause from the LS during these months. Concurrent with the increased probability of seeing ozone in high ozone concentration bins is the gradual decline in probability of filling the low ozone concentration bins from March to June (Figure 13a). Note that the probability is a maximum at the bin centered at 75 ppbv during DJF. The maximum shifts to the bin centered at $165 \mathrm{ppbv}$ in June (Figure 13a).

[31] The specific shape of the monthly ozone PDF (Figure 13a) suggests multimode probability distribution. To illustrate this multimode feature of the tropopause ozone, the monthly ozone PDF is fitted with a bimodal lognormal distribution defined as

$$
\begin{aligned}
\frac{d n}{d O_{3}}= & \frac{N(1)}{\sqrt{2 \pi} O_{3} \ell n \sigma(1)} \exp \left\{-\frac{\ln ^{2}\left(O_{3} / a(1)\right)}{2 \ln ^{2} \sigma(1)}\right\}+\frac{N(2)}{\sqrt{2 \pi} O_{3} \ell n \sigma(2)} \\
& \cdot \exp \left\{-\frac{\ln ^{2}\left(O_{3} / a(2)\right)}{2 \ln ^{2} \sigma(2)}\right\}
\end{aligned}
$$

where $N(i)$ is the total area normalized probability (\%) of the $i$ th mode $(i=1,2), a(i)$ is the $i$ th associated mode probability $(\%)$, and $\sigma(i)$ is the $i$ th associated standard deviation $(\%)$ of the lognormal expression. The derived 


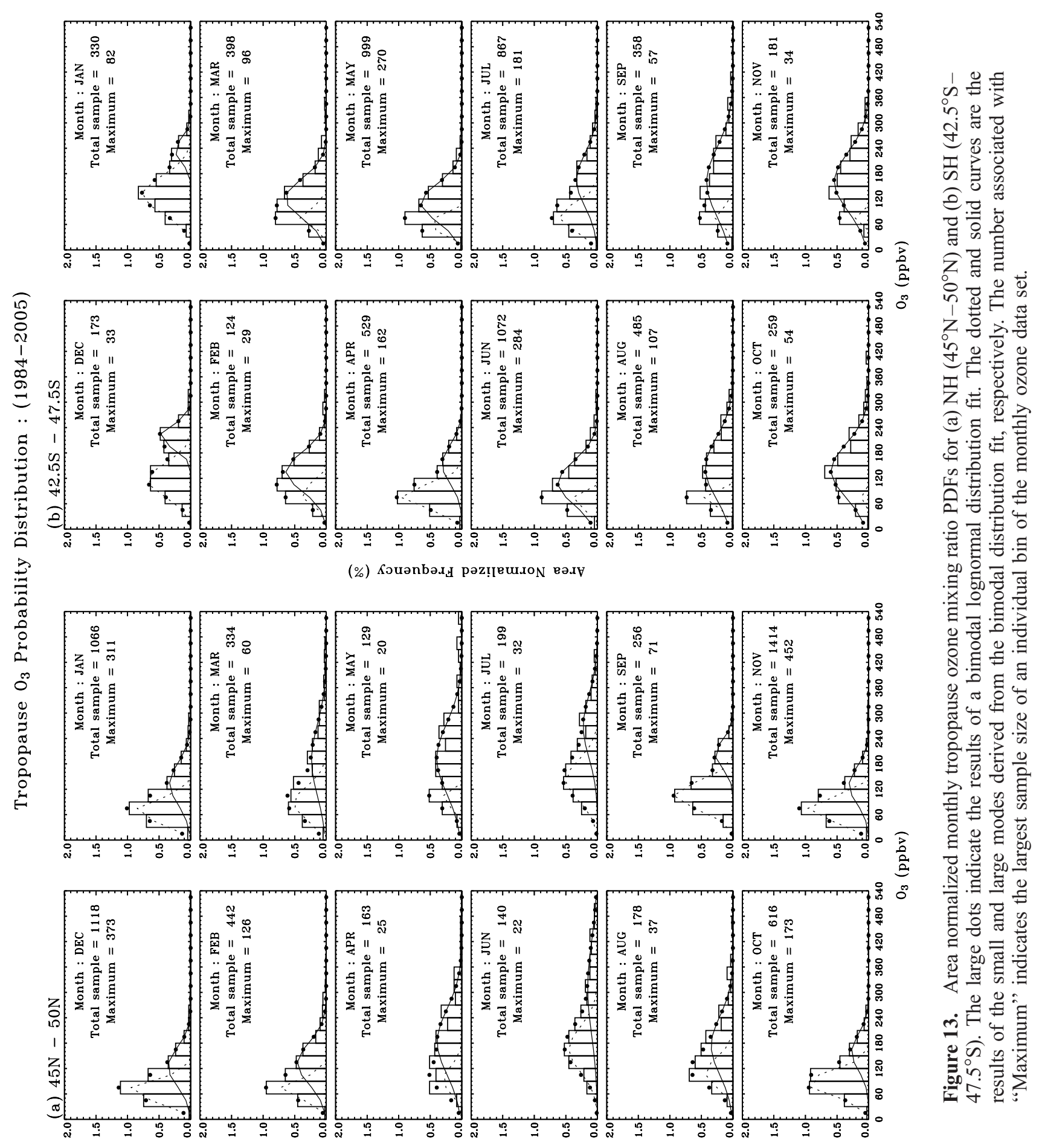

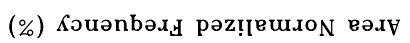


bimodal lognormal distribution for the northern midlatitude tropopause ozone measurements is superimposed onto the PDF plot in Figure 13a. The calculated correlation coefficient between PDF data and the results from the model fitting ranges between 0.999 and 0.954, suggesting that the tropopause ozone PDF can be adequately represented by a bimodal lognormal distribution, as shown in Figure 13a.

[32] The model analysis of the northern midlatitude ozone PDFs indicates that the small PDF mode (centered at 75 ppbv) during DJF almost completely disappears in June-July, while the large PDF mode (centered at $135 \mathrm{ppbv}$ ) in DJF is enhanced along with the appearance of an even larger mode centered around 300 ppbv in JuneJuly (Figure 13a). This larger mode diminishes in August-September and the PDF gradually returns to its pattern with a dominant small mode in NovemberFebruary (Figure 13a). The monthly tropopause ozone PDFs at southern midlatitudes $\left(42.5^{\circ} \mathrm{S}-47.5^{\circ} \mathrm{S}\right)$ are displayed in Figure 13b. The southern ozone PDFs also exhibit bimodal distributions, but with a smaller spread and shorter tail of high ozone values than the northern PDFs. In addition, while the large mode of the ozone PDF becomes the fully dominant mode in early spring (September) in the $\mathrm{SH}$, it is in the late spring (May) in the NH.

[33] The monthly tropopause ozone PDFs for ozonesondes from Hohenpeissenberg and Lauder are shown in Figures $14 \mathrm{a}$ and $14 \mathrm{~b}$, respectively. The shape of the ozonesonde PDFs is notably narrower than that of SAGE II, strongly suggesting regional characteristics of the ozonesonde measurements. Nevertheless, the bimodal feature and seasonal shift of the peak of the ozonesonde PDFs are evident. Interestingly, the ozone PDF spread being smaller at Lauder than at Hohenpeissenberg (Figure 14) is also consistent with the difference in the spread of the SAGE II ozone PDFs between the southern midlatitudes and the northern midlatitudes (Figure 13), likely because of different ozone sources and transport/mixing processes between the $\mathrm{NH}$ and the $\mathrm{SH}$.

\subsubsection{Tropopause Ozone Long-Term Record}

[34] Time series of tropopause ozone between 1984 and 2005 derived from zonal medians of the SAGE II measurements are compared with seasonal ozonesonde medians from Hohenpeissenberg (1985-2005) and Lauder (19862005) at corresponding latitudes in Figures $15 \mathrm{a}$ and $15 \mathrm{~b}$, respectively. The SAGE II data gap from early 1991 to late 1993 is a consequence of unusually high aerosol loading from the June 1991 Mt. Pinatubo volcanic eruption, which interrupted the SAGE II ozone retrieval in the UTLS [Cunnold et al., 1996]. Generally speaking, the long-term tropopause ozone records from SAGE II and ozonesondes exhibit similar seasonal fluctuations. The agreement between SAGE II and Hohenpeissenberg ozonesondes is better in winter than in summer (Figure 15a). This seasonal feature suggests relatively more uniform zonal ozone distribution at northern midlatitudes during winter than during summer, as indicated in Figures $12 \mathrm{a}$ and $12 \mathrm{c}$. In addition, the SAGE II seasonal record in the $\mathrm{NH}$ exhibits much larger zonal ozone variabilities in summer than in winter (Figure 15a), consistent with the ozone PDF spread being larger in summer months than in winter months, as shown in Figure 13a. In the case of Lauder ozonesondes, the seasonal record on average is about a factor of 1.5 smaller than SAGE II. The reason for this difference is because the Lauder ozonesonde is located in a geographic region in which the multiyear seasonal ozone median is systematically smaller than the ozone median in the remaining area at similar latitudes, as shown in Figure 12. Presumably the agreement between the SAGE II and Lauder records would be much better if the SAGE II data were restricted to locations close Lauder.

\section{Summary, Discussions, and Conclusions}

[35] The newly revised SAGE II satellite ozone data (version 6.2) between 1984 and 2005 have been used to develop a monthly zonal median ozone climatology in the midlatitude UTLS using the thermal tropopause as a height reference. The characteristics of the derived SAGE II midlatitude UTLS ozone climatology are consistent with the ozonesonde climatology of Logan [1999a] in many respects, including (1) the ozone seasonal cycle at the tropopause and in the UT, (2) a broad summer UT ozone maximum in the $\mathrm{NH},(3)$ a rapid phase change in the annual cycle of ozone across the tropopause in the $\mathrm{NH}$, (4) the spring ozone maximum just above the tropopause, and (5) the non-Gaussian ozone PDFs at the tropopause. This consistency reinforces the confidence in SAGE II satellite ozone remote sensing in the UTLS.

[36] Most importantly, the large number of SAGE II satellite midlatitude ozone data in the $\mathrm{NH}$ as well as in the $\mathrm{SH}$ facilitate not only the development of the monthly ozone climatology but also the exploration of the difference in ozone behavior between the $\mathrm{NH}$ and the $\mathrm{SH}$ in great detail. The results of the present study reveals a different monthly evolution in the tropopause ozone between the $\mathrm{NH}$ and the SH. While the tropopause ozone maximum in the $\mathrm{NH}$ occurs first at about $40^{\circ} \mathrm{N}$ in the spring, the maximum ozone in the $\mathrm{SH}$ occurs first at high latitudes in late winter. In the $\mathrm{NH}$, the ozone maximum at $65^{\circ} \mathrm{N}$ occurs about $1-$ 1.5 months later than the maximum near $40^{\circ} \mathrm{N}$. In the $\mathrm{SH}$, the ozone peak at $30^{\circ} \mathrm{S}$ takes place $2-3$ months later than the maximum at southern high latitudes. An additional difference in the properties of the midlatitude UTLS ozone between the $\mathrm{NH}$ and the $\mathrm{SH}$ is in the vertical structure of the monthly ozone evolution. This study shows that, in the $\mathrm{SH}$, the monthly ozone evolution at the tropopause and $1 \mathrm{~km}$ below the tropopause resembles that at $2 \mathrm{~km}$ above the tropopause to some extent. This is not the case in the monthly ozone evolution in the NH. In terms of ozone distributions relative to the dynamical tropopause, i.e., 2.5 PVU, no such resemblance is found between the ozone at PV tropopause $+2 \mathrm{~km}$ and ozone at the PV tropopause and tropopause $-1 \mathrm{~km}$ in both hemispheres.

[37] Those differences in ozone characteristics near the tropopause between the northern and southern midlatitudes is almost certainly related to strong anthropogenic ozone sources in the extratropical NH [e.g., Lelieveld and Dentener, 2000; Fusco and Logan, 2003], and to the differences between the strengths of winter polar vortices and synoptic-scale atmospheric disturbances in the two hemispheres. The winter polar vortex in the $\mathrm{SH}$ is much stronger than in the NH, while the synoptic-scale disturbances are much weaker in the $\mathrm{SH}$ than in the $\mathrm{NH}$ [Rosenlof, 


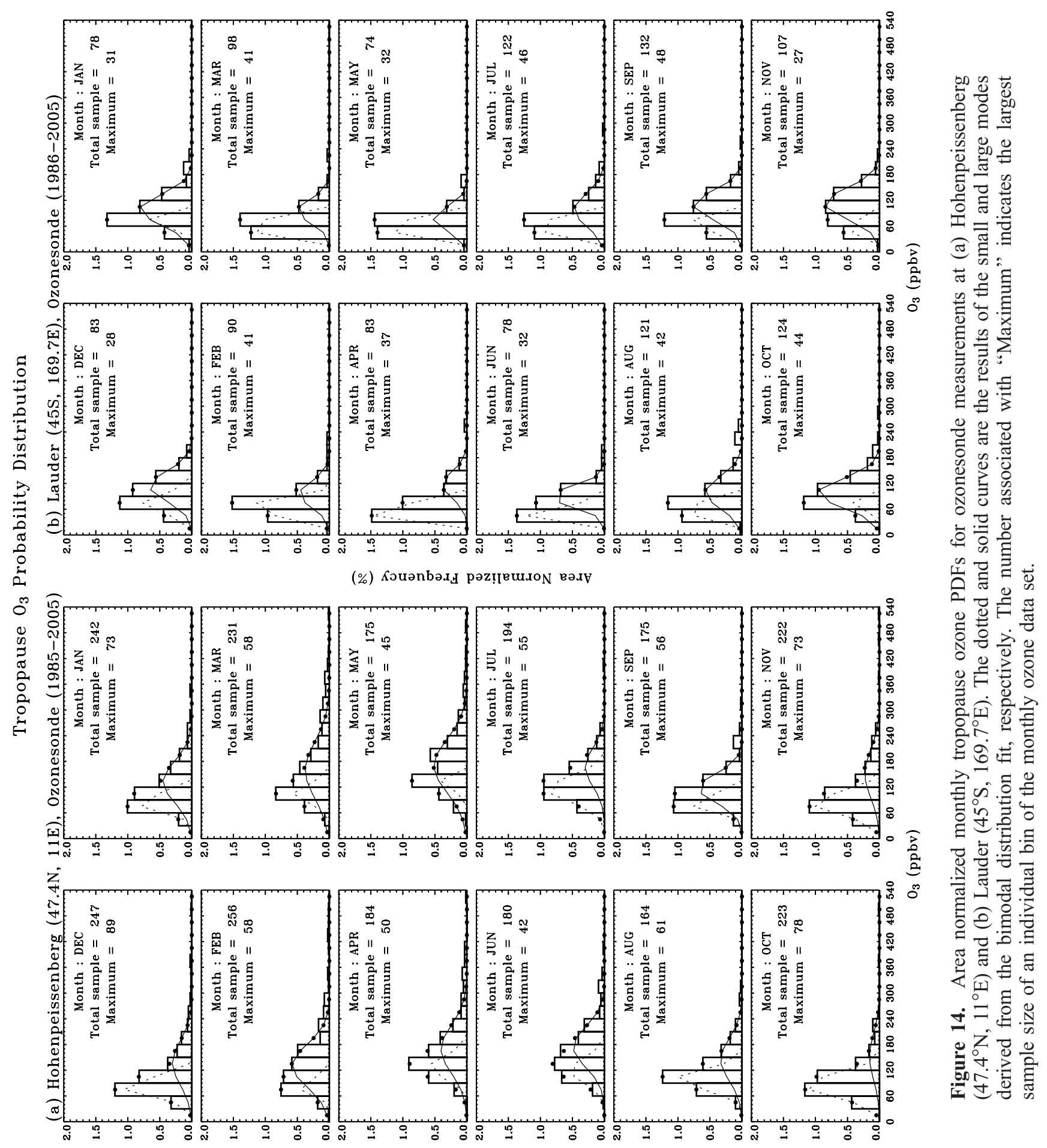

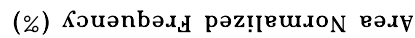




\section{SAGE II and Ozonesonde Tropopause Median $0_{3}$ Comparison}

(a)

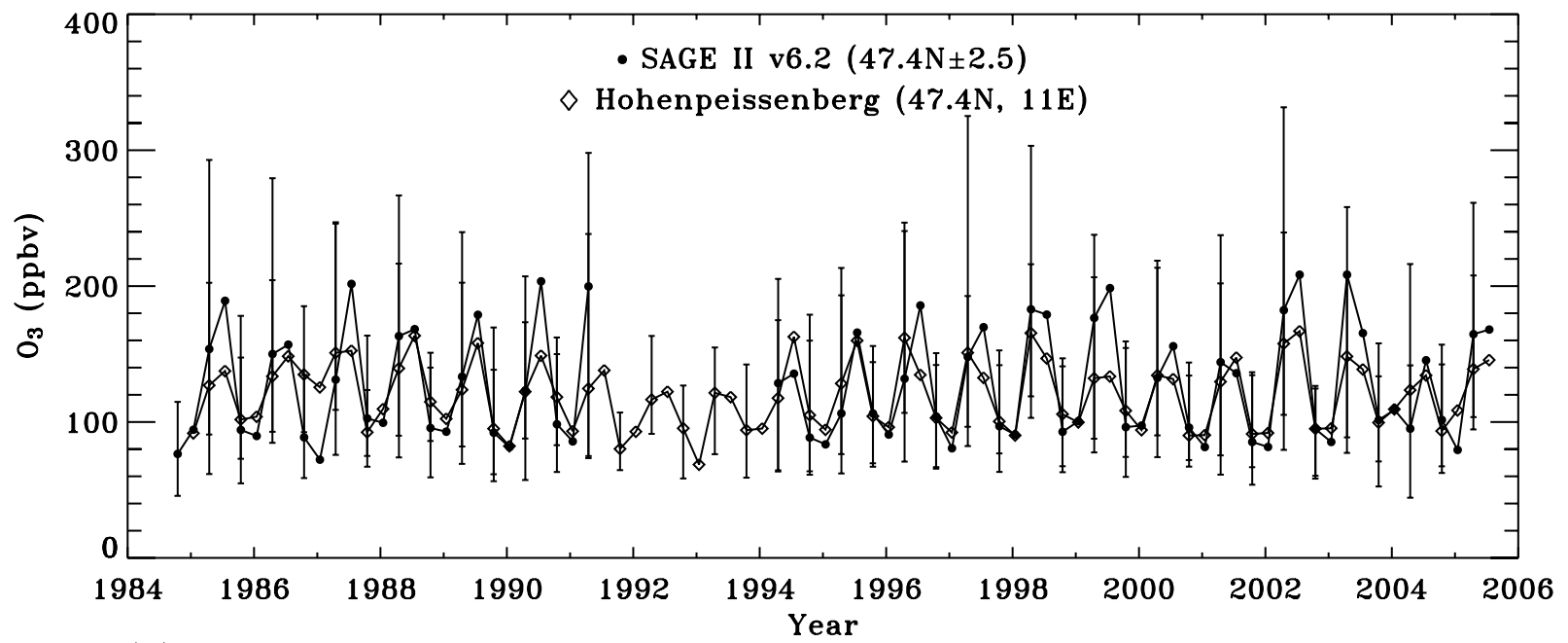

(b)

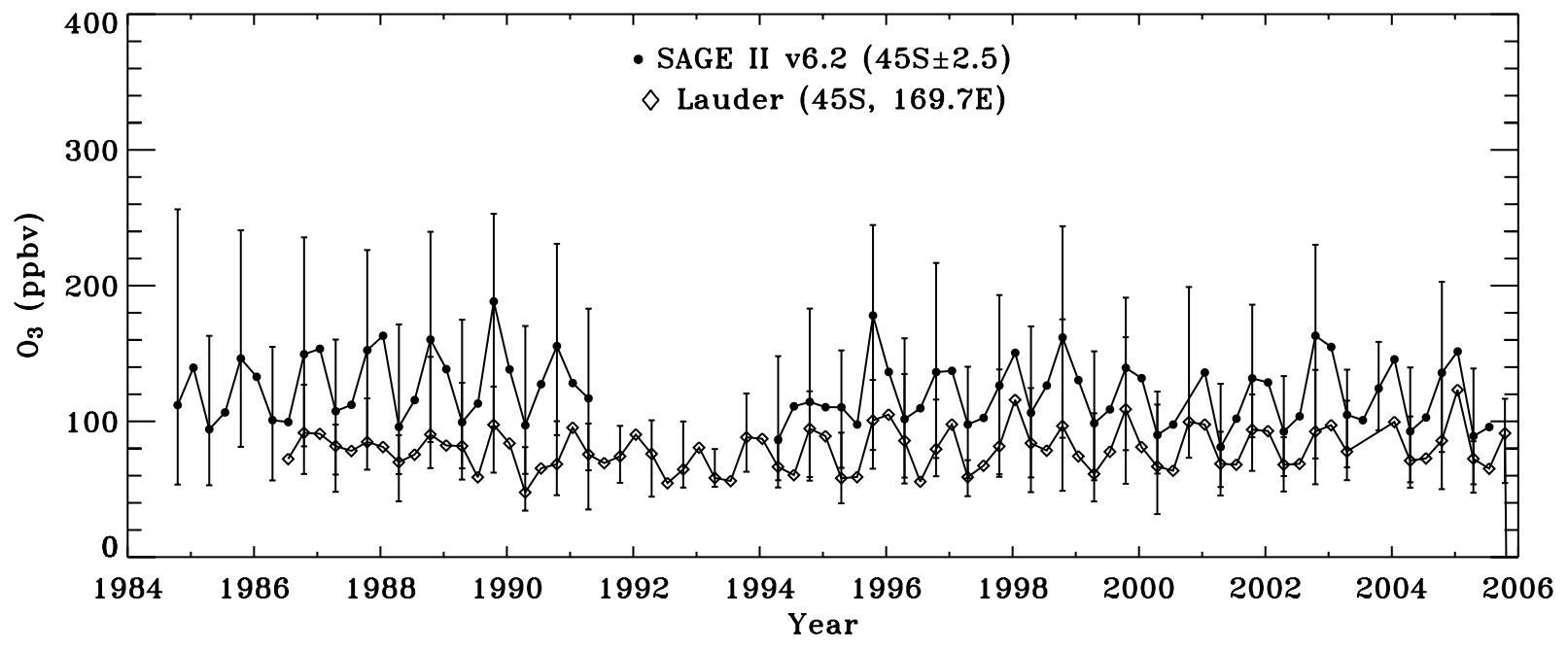

Figure 15. Comparison of the SAGE II seasonal ozone data record (1984-2005) (dots) with ozonesondes (diamonds) from (a) Hohenpeissenberg $\left(47.4^{\circ} \mathrm{N}, 11^{\circ} \mathrm{E}\right)$ and (b) Lauder $\left(45^{\circ} \mathrm{S}, 169.7^{\circ} \mathrm{E}\right)$. The vertical bar corresponds to seasonal ozone variability.

1995]. Consequently, descent in the Antarctic vortex plays a predominant role in controlling the $\mathrm{SH}$ ozone distribution, while both descent and synoptic-scale disturbances influence the ozone distribution in the NH. Pan et al. [1997] noted that hemispherical differences in the strength of STE and in poleward transport associated with Hadley circulation contribute to hemispheric asymmetry in LS water vapor [see also Rosenlof et al., 1997]. An additional influence is the hemispherical difference in ozone related heterogeneous chemistry in the presence of polar stratospheric clouds (PSC) [Solomon, 1990]. As PSCs are more abundant and persistent in the SH than in the NH [McCormick et al., 1982], the LS ozone at southern high latitudes is being lost in September-October and the effects of this loss can be advected to lower latitudes as the vortex breaks up.

[38] To explore the tropopause ozone behavior over a spectrum of concentrations, the present study investigates the monthly evolution of the tropopause ozone PDFs. The results indicate that the probability of high ozone concen- trations increases and the probability of low ozone concentrations declines in the spring and early summer months, reflecting possible stratosphere to troposphere transport during this time of year. In the late summer and fall months, the probability of high ozone concentrations declines concurrent with the enhancement of the probability of low ozone concentrations, suggesting possible troposphere to stratosphere transport in late summer and fall.

[39] Furthermore, this study has demonstrated that the midlatitude tropopause ozone PDF can be represented adequately by a bimodal lognormal distribution. Interestingly, the intensification/weakening of the large/small mode of the total mode area, $N$, correlates well with the enhancement/decline of the tropopause ozone concentration. This feature suggests that the large (small) modes in the bimodal distribution are associated with stratospheric (tropospheric) air at the tropopause. The bimodal distribution in the tropopause ozone PDF is also indicative of the presence of air characteristic of both the stratosphere and the tropo- 
sphere, as well as STT and TST exchange processes that occur all year round, consistent with a transition zone near the tropopause as suggested in the literature [e.g., Logan, 1999a; Rood et al., 2000].

[40] It is noted that the relative roles of transport and chemistry on UT ozone are not well understood or quantified at present. The distinct seasonal enhancement in the midlatitude ozone distribution in the UT from late winter to early summer suggests photochemical production and possible STT, and the ozone decline around the tropopause during late summer through early winter could relate to chemical ozone loss and/or absence of an ozone source or TST [e.g., Rosenlof et al., 1997; Wang et al., 1998b]. The occurrence of high ozone loadings in the UT during the summer months is also consistent with the high summer statistics of the Rossby wave breaking activities [Postel and Hitchman, 1999; Jing et al., 2004]. Furthermore, in summer, active photochemical ozone production can also contribute to elevated ozone concentrations near the tropopause [e.g., Bethan et al., 1996]. Recent global three-dimensional chemistry-transport model studies indicate that tropospheric ozone in the extratropical NH is strongly affected by industrial and fossil fuel-related emission [Lelieveld and Dentener, 2000; IGOS, 2004], and that increases in methane are responsible for approximately one fifth of the anthropogenically induced increase in tropospheric ozone at northern midlatitudes [Fusco and Logan, 2003]. Further detailed analysis using global atmospheric chemistry-transport models to quantify the relative roles of chemistry and dynamics in controlling the UTLS ozone and their contributions to the different ozone properties between the two hemispheres is warranted.

[41] Furthermore, the details of where tropospheric air enters the stratosphere and the scales involved are still heavily debated [Stohl et al., 2003b]. It is acknowledged that extratropical STE occurs in both directions, i.e., STT and TST [Holton et al., 1995; Chen, 1995; Stohl et al., 2003a, 2003b]. How stratospheric air is transported into the troposphere has been the focus for some time (see all the references given by Stohl et al. [2003b, p. 5, paragraph 16]), and tropopause folds and cutoff lows are generally accepted as especially important STT processes. As for the TST, it has received much less attention in the past: studies on TST have been reported in the literature only recently (see the references given by Stohl et al. [2003b, p. 5, paragraph 18]). Nevertheless, STE remains inadequately quantified, according to Stohl et al. [2003a, 2003b], because of the difficulties in resolving filamentary flow structures and air mass residence time after they have been transported across the tropopause. To address these considerations requires highresolution Lagrangian trajectory analysis with ozone chemistry included [Stohl, 2001; Stohl et al., 2003a, 2003b; Wernli and Bourqui, 2002] and this is beyond the scope of the present investigation. Satellite instruments, on the other hand, can provide valuable observational information on STE in a temporally and spatially integrated sense.

[42] This midlatitude monthly ozone climatology, relative to the tropopause, from SAGE II can be used to initialize global chemistry-transport models and satellite data retrievals. With its sufficient data coverage at midlatitude in both hemispheres, the present ozone climatology complements the existing climatologies in the midlatitude UTLS [e.g.,
Fortuin and Kelder, 1998; Logan, 1999a, 1999b; Logan and McPeters, 1999]. Finally, the entire data set of the SAGE II monthly ozone climatology shown in Figures 4 and 5 is provided as auxiliary material to the present report. Included in the auxiliary material is also the ozone climatology data referenced to the tropopause. It is noted that the user of this SAGE II climatology should be aware of the low ozone value bias below about $10 \mathrm{~km}$. In the future, this ozone climatology will be updated as new and improved SAGE II ozone retrievals become available.

[43] Acknowledgments. The authors would like to thank Jennifer A. Logan and an anonymous reviewer for their helpful and constructive suggestions and comments. Thanks are also due to Robert B. Pierce and David B. Considine of the NASA Langley Research Center and John Anderson of Hampton University for their many useful discussions. The SAGE II data are obtained from the ASDC at the NASA Langley Research Center. The ozonesonde data are provided by the World Ozone Data Center, Toronto, Ontario, Canada. P.-H. Wang is supported by the NASA Atmospheric Chemistry, Modeling, and Analysis Program (NAS1-02058).

\section{References}

Bethan, S., G. Vaughan, and S. J. Reid (1996), A comparison of ozone and thermal tropopause heights and the impact of tropopause definition on quantifying the ozone content of the troposphere, Q.J.R. Meteorol. Soc., $122,929-944$.

Chen, P. (1995), Isentropic cross-tropopause mass exchange in the extratropics, J. Geophys. Res., 100, 16,661-16,673.

Chu, W. P., M. P. McCormick, J. Lenoble, C. Brogniez, and P. Pruvost (1989), SAGE II inversion algorithm, J. Geophys. Res., 94, 8339-8351.

Cunnold, D. M., L. Froidevaux, J. Russel, B. Connor, and A. Roche (1996), An overview of UARS ozone validation based primarily on intercomparisons among UARS and SAGE II measurements, J. Geophy. Res., 101, $10,335-10,350$

Dunkerton, T. J. (1995), Evidence of meridional motion in the summer lower stratosphere adjacent to monsoon regions, J. Geophys. Res., 100, $16,675-16,688$.

Fortuin, J. P. F., and H. Kelder (1998), An ozone climatology based on ozonesonde and satellite measurements, J. Geophys. Res., 103, 31,70931,734 .

Fusco, A. C., and J. A. Logan (2003), Analysis of 1970-1995 trends in tropospheric ozone at Northern Hemisphere midlatitudes with the GEOSCHEM model, J. Geophys. Res., 108(D15), 4449, doi:10.1029/ 2002JD002742.

Holton, J. R., P. H. Haynes, M. E. McIntyre, A. R. Douglass, R. B. Rood, and L. Pfister (1995), Stratosphere-troposphere exchange, Rev. Geophys, $33,403-439$.

Integrated Global Observing Strategy (2004), An Integrated Global Atmospheric Chemistry Observation Theme, ESA SP-1282, GAW 159, WMO TD 1235, $54 \mathrm{pp}$.

Intergovernmental Panel on Climate Change (2001), Climate Change 2001: The Scientific Basis-Contribution of Working Group I to the Third Assessment Report of the Intergovernmental Panel on Climate, edited by J. T. Houghton et al., 881 pp., Cambridge Univ. Press, Cambridge, New York.

Iyer, N., J. M. Zawodny, L. W. Thomason, and S. P. Burton (2003), Recent advances in SAGE II data processing: Version 6.2, Eos Trans. $A G U$, 84(46), Fall Meet. Suppl., Abstract A42C-0771.

Jing, P., D. M. Cunnold, H. J. Wang, and E.-S. Yang (2004), Isentropic cross-tropopause ozone transport in the Northern Hemisphere, J. Atmos. Sci., 61, $1068-1078$.

Jing, P., M. D. Cunnold, H. J. Wang, and E.-S. Yang (2005), Influence of isentropic mixing on seasonal ozone variations in the lower stratosphere and subtropical upper troposphere, J. Geophys. Res., 110, D10110, doi:10.1029/2004JD005416.

Kent, G. S., D. M. Winker, M. T. Osborn, M. P. McCormick, and K. M. Skeens (1993), A model for the separation of cloud and aerosol in SAGE II occultation data, J. Geophys. Res., 98, 20,725-20,735.

Lelieveld, J., and F. J. Dentener (2000), What controls tropospheric ozone?, J. Geophys. Res., 105, 3531-3551.

Logan, J. A. (1985), Tropospheric ozone: Seasonal behavior, trends and anthropogenic influence, J. Geophys. Res., 90, 10,463-10,482.

Logan, J. A. (1999a), An analysis of ozonesonde data for the troposphere: Recommendations for testing 3-D models and development of a gridded climatology for tropospheric ozone, J. Geophys. Res., 104, 16,11516,149 . 
Logan, J. A. (1999b), An analysis of ozonesonde data for the lower stratosphere: Recommendations for testing models, J. Geophys. Res., 104, $16,151-16,170$

Logan, J. A., and R. D. McPeters (1999), Ozone climatology, in Models and Measurements Intercomparison II, edited by J. H. Park et al., NASA Tech. Memo. NASA/TM-1999-209554, 307-362.

McCormick, M. P. (1987), SAGE II: An overview, Adv. Space Res., 7, 319-326.

McCormick, M. P., H. M. Steele, P. Hamill, W. P. Chu, and T. J. Swissler (1982), Polar stratospheric cloud sightings by SAM II, J. Atmos. Sci., 39, $1387-1394$

Pan, L., S. Solomon, W. Randel, J.-F. Lamarque, P. Hess, J. Gille, E.-W. Chiou, and P. McCormick (1997), Hemispheric asymmetries and seasonal variations of the lowermost stratospheric water vapor and ozone derived from SAGE II data, J. Geophys. Res., 102, 28,177-28,184.

Postel, A. P., and M. H. Hitchman (1999), A climatology of Rossby wave breaking along the subtropical tropopause, J. Atmos. Sci., 56, 359-373.

Randel, W. J., F. Wu, and D. J. Gaffen (2000), Interannual variability of the tropical tropopause derived from radiosonde data and NCEP reanalysis, J. Geophys. Res., 105, 15,509-15,523.

Rood, R. B., A. R. Douglass, M. C. Cerniglia, L. C. Sparling, and J. E. Nielsen (2000), Seasonal variability of middle-latitude ozone in the lowermost stratosphere derived from probability distribution functions, J. Geophys. Res., 105, 17,793-17,805.

Rosenlof, K. H. (1995), Seasonal cycle of the residual mean meridional circulation in the stratosphere, J. Geophys. Res., 100, 5173-5191.

Rosenlof, K. H., A. F. Tuck, K. K. Kelly, J. M. Rissel III, and M. P. McCormick (1997), Hemispheric asymmetries in water vapor and inferences about transport in the lower stratosphere, J. Geophys. Res., 102 , $13,213-13,234$

Schoeberl, M. R. (2004), Extratropical stratosphere-troposphere mass exchange, J. Geophys. Res., 109, D13303, doi:10.1029/2004JD004525.

Seo, K.-H., and K. P. Bowman (2002), Lagrangian estimate of global stratosphere-troposphere mass exchange, J. Geophys. Res., 107(D21), 4555, doi:10.1029/2002JD002441.

Solomon, S. (1990), Progress toward a quantitative understanding of Antarctic ozone depletion, Nature, 347, 347-354.

Stohl, A. (2001), A 1-year Lagrangian "climatology" of airstreams in the Northern Hemisphere tropospheric and lowermost stratosphere, J. Geophys. Res., 106, 7263-7279.

Stohl, A., et al. (2003a), A new perspective of stratosphere-troposphere exchange, Bull. Am. Meteorol. Soc., 84, 1565-1573.
Stohl, A., et al. (2003b), Stratosphere-troposphere exchange: A review, and what we have learned from STACCATO, J. Geophys. Res., 108(D12), 8516, doi:10.1029/2002JD002490.

Wang, H. J., D. M. Cunnold, L. W. Thomason, J. M. Zawodny, and G. E. Bodeker (2002), Assessment of SAGE version 6.1 ozone data quality, J. Geophys. Res., 107(D23), 4691, doi:10.1029/2002JD002418.

Wang, P.-H., P. Minnis, M. P. McCormick, G. S. Kent, and K. M. Skeens (1996), A 6-year climatology of cloud occurrence frequency from SAGE II observations (1985-1990), J. Geophys. Res., 101, 29,407-29,429.

Wang, P.-H., D. M. Cunnold, J. M. Zawodny, R. B. Pierce, J. R. Olson, G. S Kent, and K. M. Skeens (1998a), Seasonal ozone variations in the isentropic layer between 330 and $380 \mathrm{~K}$ as observed by SAGE II: Implications of extratropical cross-tropopause transport, J. Geophys. Res., 103 , 28,647-28,659

Wang, P.-H., D. Rind, C. R. Trepte, G. S. Kent, G. K. Yue, and K. M. Skeens (1998b), An empirical model study of the tropospheric meridional circulation based on SAGE II observations, J. Geophys. Res., 103, $13,801-13,818$

Wernli, H., and M. Bourqui (2002), A Lagrangian "1-year climatology" of (deep) cross-tropopause exchange in the extratropical Northern Hemisphere, J. Geophys. Res., 107(D2), 4021, doi:10.1029/2001JD000812.

World Meteorological Organization (1957), Definition of the tropopause, WMO Bull., 6, 136.

World Meteorological Organization (1998), Assessment of trends in the vertical distribution of ozone, Global Ozone Res. Monit. Proj. Rep. 44, 289 pp., Geneva, Switzerland.

World Meteorological Organization (2003), Scientific assessment of ozone depletion: 2002, Global Ozone Res. Monit. Proj. Rep. 47, 498 pp., Geneva, Switzerland.

G. E. Bodeker, National Institute of Water and Atmospheric Research, Lauder, Central Otago 9182, New Zealand.

V. G. Brackett, Science Applications International Corp., Hampton, VA 23681, USA.

D. M. Cunnold, P. Jing, and H. J. Wang, School of Earth and Atmospheric Sciences, Georgia Institute of Technology, Atlanta, GA 30332, USA.

J. Fishman, C. R. Trepte, and J. M. Zawodney, Science Directorate, NASA Langley Research Center, Hampton, VA 23681, USA.

P.-H. Wang, Science and Technology Corporation, Hampton, VA 23666, USA. (p.wang@larc.nasa.gov) 